Portland State University

PDXScholar

TREC Final Reports

Transportation Research and Education Center

(TREC)

$10-2020$

\title{
The Role of Bus Stop Features in Facilitating Accessibility
}

\author{
Keith Bartholomew \\ University of Utah \\ Ja Young Kim \\ University of Utah \\ Divya Chandrasekhar \\ University of Utah \\ Reid Ewing \\ University of Utah \\ Arlie Adkins \\ University of Arizona
}

See next page for additional authors

Follow this and additional works at: https://pdxscholar.library.pdx.edu/trec_reports

Part of the Transportation Commons, Urban Studies Commons, and the Urban Studies and Planning

Commons

Let us know how access to this document benefits you.

\section{Recommended Citation}

Bartholomew, K., Kim, J., Chandrasekhar, D., Ewing, R., Adkins, A. \& Jensen, S. The Role of Bus Stop Features In Facilitating Accessibility. NITC-RR-1214. Portland, OR: Transportation Research and Education Center (TREC), 2020. https://dx.doi.org/10.15760/trec.254

This Report is brought to you for free and open access. It has been accepted for inclusion in TREC Final Reports by an authorized administrator of PDXScholar. Please contact us if we can make this document more accessible: pdxscholar@pdx.edu. 


\section{Authors}

Keith Bartholomew, Ja Young Kim, Divya Chandrasekhar, Reid Ewing, Arlie Adkins, and Samuel Jensen 


\title{
THE ROLE OF BUS STOP FEATURES IN FACILITATING ACCESSIBILITY
}

\section{Final Report}

\author{
NITC-RR-1214 \\ by
Keith Bartholomew
Ja Young Kim
Reid Ewing
University of Utah \\ Divya Chandrasehkar \\ Arlie Adkins \\ Samuel Jensen \\ University of Arizona
}

for

National Institute for Transportation and Communities (NITC)

P.O. Box 751

Portland, OR 97207

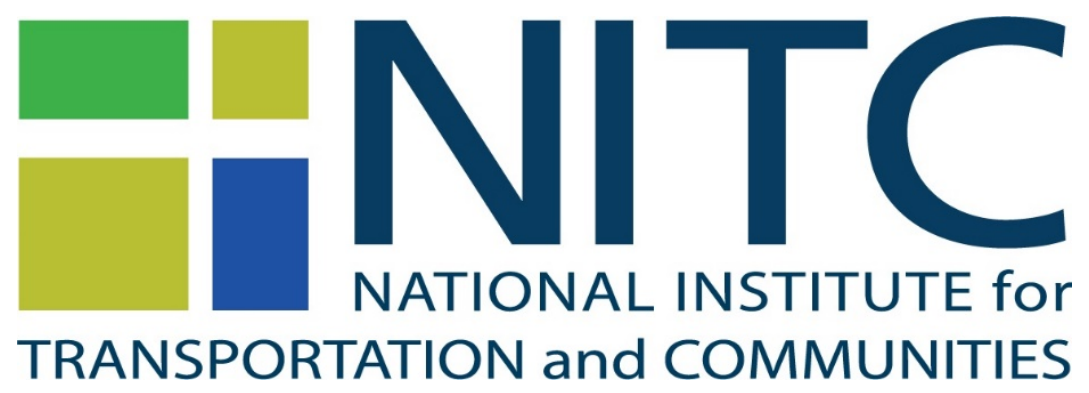

October 2020 


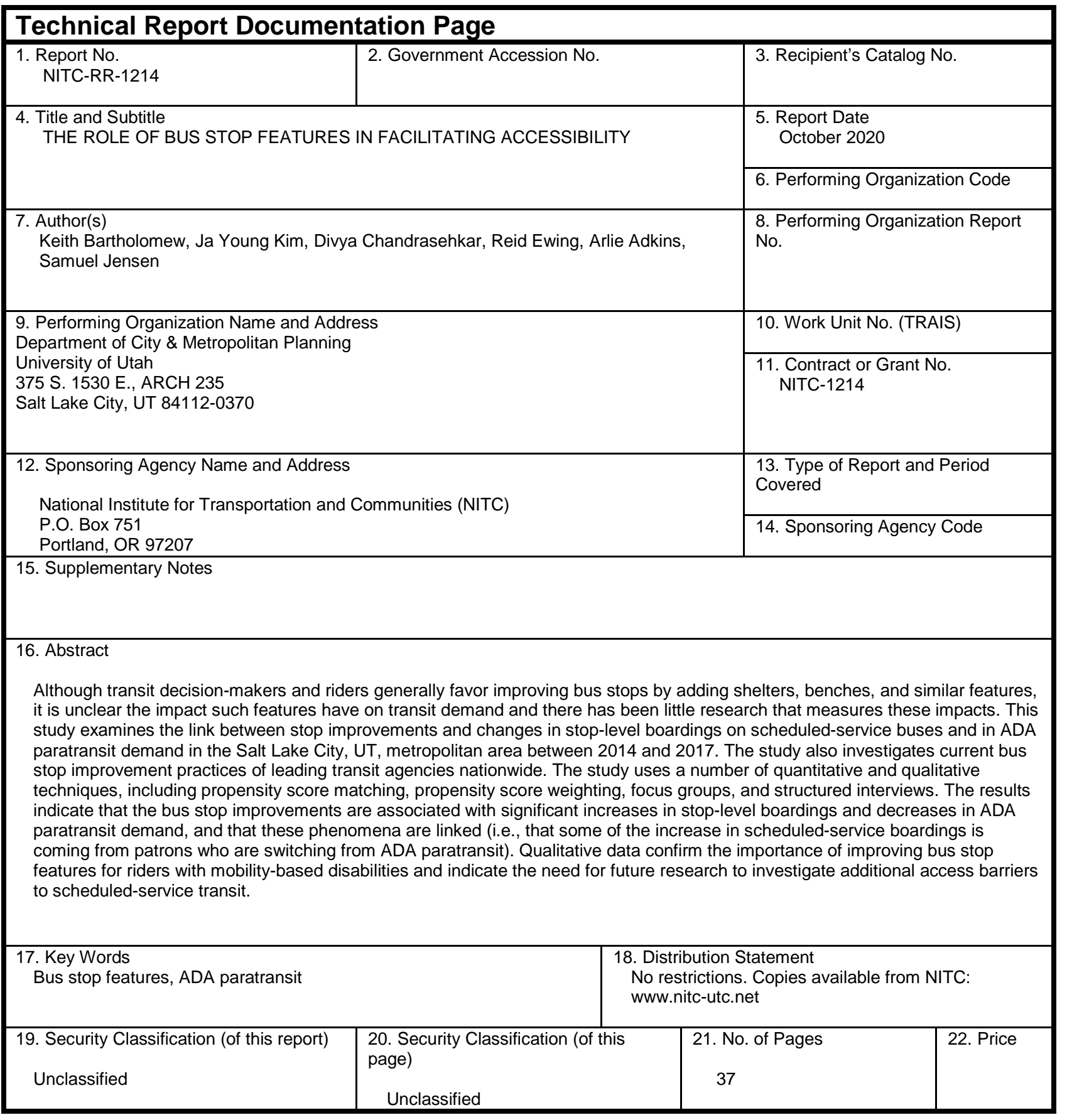




\section{ACKNOWLEDGEMENTS}

The authors would like to acknowledge support from the National Institute for Transportation and Communities (NITC; grant number 1214), a U.S. DOT University Transportation Center, and the Utah Department of Transportation (Grant number 198318).

\section{DISCLAIMER}

The contents of this report reflect the views of the authors, who are solely responsible for the facts and the accuracy of the material and information presented herein. This document is disseminated under the sponsorship of the U.S. Department of Transportation University Transportation Centers Program and the Utah Department of Transportation in the interest of information exchange. The U.S. Government and the Utah Department of Transportation assume no liability for the contents or use thereof. The contents do not necessarily reflect the official views of the U.S. Government and the Utah Department of Transportation. This report does not constitute a standard, specification, or regulation.

\section{RECOMMENDED CITATION}

Bartholomew, K., Kim, J., Chandrasekhar, D., Ewing, R., Adkins, A. \& Jensen, S. The Role of Bus Stop Features In Facilitating Accessibility. NITC-RR-1214. Portland, OR: Transportation Research and Education Center (TREC), 2020. 


\section{TABLE OF CONTENTS}

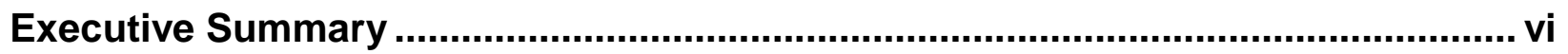

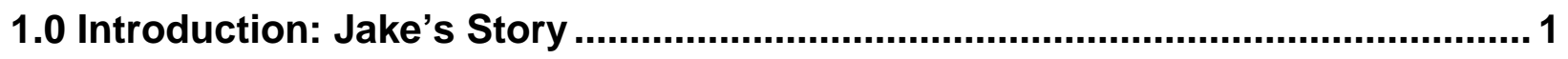

2.0 The Bus Stop: The Point of First Contact ......................................................... 2

3.0 Agency Bus Stop Improvement Guidelines ............................................... 7

4.0 Quantitative Links between Stop Improvements and Ridership Demand........ 10

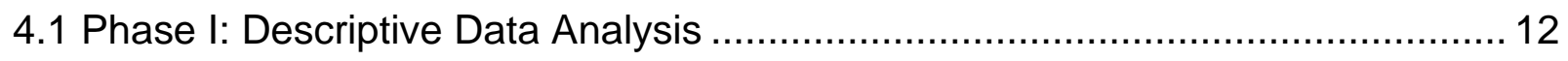

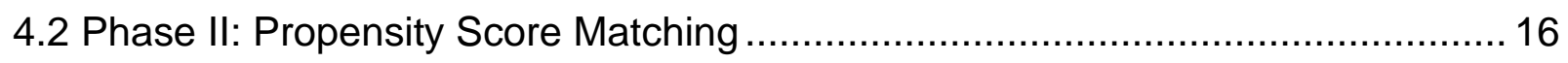

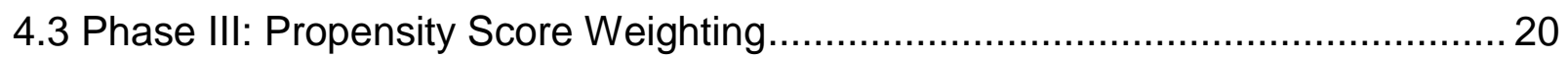

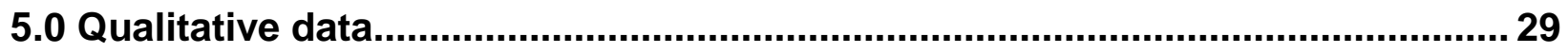

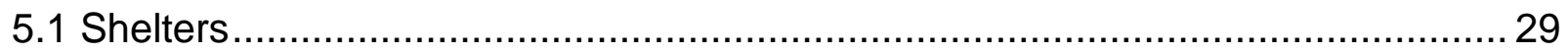

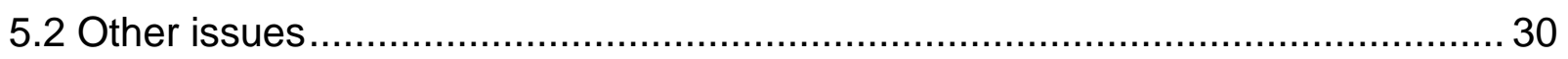

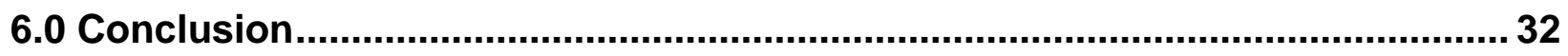

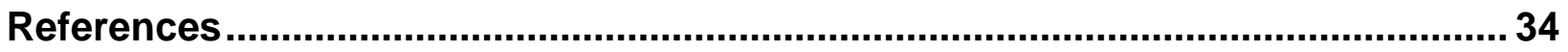

APPENDIX A: Step-Wise Analytical Methodology for Phase III Analysis 


\section{LIST OF TABLES}

Table 3.1: Inventory of Bus Stop Improvement Placement and Design Guidelines for the

Largest U.S. Bus Transit Operators ....................................................... 8

Table 4.1: Variable Description for Phase II .............................................................. 17

Table 4.2: Mean Differences Between Improved and Unimproved Salt Lake County Bus

Stops for Observed Covariates............................................................. 18

Table 4.3: Effect of Bus Stop Improvement on Changes in Stop-Level Bus Boardings and Paratransit Demand ...................................................................... 20

Table 4.4. Description of Variables for Phase III ...................................................... 22

Table 4.5: Bus Stop Improvements and Change in Bus and ADA Paratransit Ridership Using Propensity Score Weighting …................................................. 24

Table 4.6: Bus Stop Improvements and Changes in Ramp Deployment and Freedom

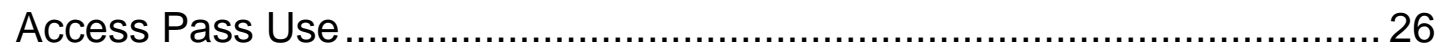

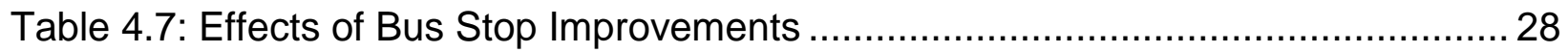




\section{LIST OF FIGURES}

Figure 2.1. An EyeStop bus stop designed by engineers and architects at MIT. ............ 3

Figure 2.2. A bus stop in the Seocho District of Seoul .............................................. 4

Figure 2.3. The "Sorriest Bus Stop in North America" for 2018.................................. 4

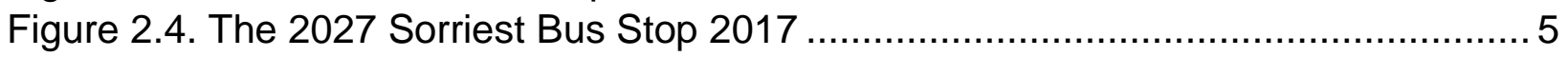

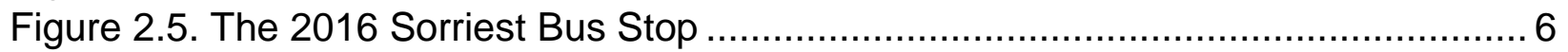

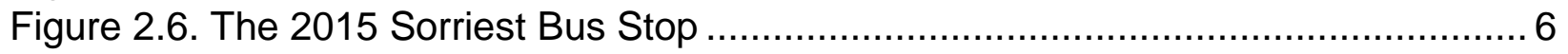

Figure 4.1. Bus stop improvement sites along the \#41 bus line................................ 12

Figure 4.2. Before and after bus stop facility improvements along the \#41 bus line...... 13

Figure 4.3. The treatment and control group sections of the \#41 bus line.................... 13

Figure 4.4. January-June bus boardings along the \#41 bus line in 2014 and 2015. ..... 14

Figure 4.5. January-June ADA paratransit pick-ups along the \#41 bus line in 2014 and 2015.

Figure 4.6. ADA paratransit deployment trend in entire UTA service area, 2013-2016. 15

Figure 4.7. Locations of the Salt Lake County bus stops matched using propensity scores.

Figure 4.8..Location of treated and control stops for Phase III. ................................ 21 


\section{EXECUTIVE SUMMARY}

Although transit decision-makers and riders generally favor improving bus stops by adding shelters, benches, and similar features, it is unclear the impact such features have on transit demand. The literature on the effects of bus improvements is not extensive and is primarily comprised of analyses that make use of descriptive statistics, with little or no control of possible confounding variables.

This multi-phased study analyzes bus stop improvements made by the Utah Transit Authority (UTA) to determine whether, and to what extent, the improvements are associated with changes in stop-level ridership and demand for Americans with Disabilities Act (ADA) paratransit service in the areas immediately surrounding improved bus stops. The study compares ridership and paratransit demand from before and after the improvements at the treated stops and at a set of unimproved stops selected using a variety of quantitative techniques-including propensity score matching and propensity score weighting - to control for demographic, land use, and regional accessibility influences. The study also assessed the state of the practice that the largest U.S. bus transit operators are using for making bus stop improvement decisions. The study concludes with a qualitative investigation of barriers to the use of scheduledservice transit by persons with mobility-related disabilities.

The results indicate that the bus stop improvements are associated with significant increases in stop-level boardings and decreases in ADA paratransit demand, and that these phenomena are linked (i.e., that some of the increase in scheduled-service boardings is coming from patrons who are switching from ADA paratransit). Qualitative data confirm the importance of improving bus stop features for riders with mobilitybased disabilities and indicate the need for future research to investigate additional access barriers to scheduled-service transit. These outcomes are important for transit service providers as they seek to increase overall ridership and reduce costs associated with providing paratransit service. 


\subsection{INTRODUCTION: JAKE'S STORY}

The source of this project comes from a chance encounter a member of our research team had with an alum of the University of Utah's Master of City \& Metropolitan Planning program. The encounter occurred one morning several years ago when the team member was walking to work and came upon the former student (Jake), dressed in an orange vest and hard hat, at a bus stop along 200 South in Salt Lake City. After the customary pleasantries, Jake explained that he and the team he was directing with the Utah Transit Authority (UTA) were upgrading the stop, taking it from the usual minimalist flag-sign on a pole (aka "a pole in a puddle") to a fully equipped stop(i.e., one with a shelter, a bench, a trash can, and an ADA compliant concrete pad connected to the nearby sidewalk). As our team member looked down the length of 200 South, he could see that other stops along the street had been similarly improved. Jake explained that he had recently begun working to improve bus stops on a corridor-by-corridor basis, rather than the more customary scattershot approach, on the hunch that strategically improving an entire corridor would have a bigger impact on customer satisfaction and ridership. Our team member asked if Jake was collecting data that might confirm or disprove his hunch. "I don't have time for that," was Jake's response. This research project began later that same morning.

This report on the project begins with some observations on the role of bus stops in communicating messages to communities about transit services and the value of riders. It continues with a review of the policies the largest U.S. transit agencies employ in making decisions about the improvement of bus stop features. The next section addresses the question of whether the features provided at bus stops might influence transit demand. The section reports on quantitative and qualitative methods the research team used to look at demand for both scheduled bus and ADA paratransit services. Implicit in the assessment is the question of whether the nature of bus stop features affects overall accessibility for persons with mobility-related disabilities. The report concludes with a synthesis of the team's findings and an articulation of possible future directions for related research. The appendix to the report includes a "cookbook" of methods team members employed for some of their quantitative analyses, with the hope that others may wish to pursue analyses in other communities. 


\subsection{THE BUS STOP: THE POINT OF FIRST CONTACT}

The concept of contact with a product's or service's brand is the idea that information an individual receives and encodes about a product or service comes from contacts the individual has with the product or service. Understood most broadly, "contact consists of all messages, incentives, activities, or methods by which an individual comes in contact with the brand and leaves some trace of brand information and impact" (Krugman \& Hayes, 2012, p. 440). Those contacts come in myriad forms and mediums, some of them intended and structured by the agency offering the product or service, but many more come from more informal sources, frequently that are beyond the control of the agency. "'Everything communicates,"' including "every encounter by a consumer with something that sends a message about a brand" (Moriarty \& Schultz, 2012, quoting Duncan, 1995). Hence, while some contacts (frequently, those intended by the agency) transmit positive messages, many others send messages that may be less positive.

For bus transit, the stop functions as the point of first contact between the transit operator and the customer. This, of course, is true in a tactile sense because the physical relationship between rider and bus begins at the stop, and as such the stop provides the initial definition of the relationship. But the importance of the stop goes much further by signaling the transit agency's attitude and intentions with respect to the quality of the service provided. In this sense, the characteristics of the stop serve as an extension of the agency's self-concept and it sends signals to persons outside the agency about how the agency sees itself and the value of its product. In a concrete sense (literally, as well as figuratively), the characteristics of a bus stop communicate a message to the community that surrounds that stop. It is an utterance by the transit agency not only to its current patrons, but to others in the community who might (or might not) become patrons in the future.

These utterances then embed themselves in customers' minds, influencing their concepts of service quality. What do the various physical components of transit service-bus stops as well as vehicle design, age, and cleanliness-communicate about the quality of the transit services being offered? If the features of the stop project an image of a bare-bones, minimal-investment style of service, that image is likely to be adopted by the riding public.

In addition to sending messages about the agency's self-concept regarding the quality of its services, the design of the bus stop sends implicit messages about the agency's attitude concerning its current and potential customers. Given that almost all bus riders are required to wait at a stop before the bus arrives-making time at the stop an integral part of any transit-based trip-the stop is a place where the agency acts as host to the waiting rider. Conceptually, the agency is inviting the rider into the stop environment as a person would invite someone into their home. Given that in most cases there is no human representative from the agency at the stop, the physical features of the stop serve as stand-ins for the agency-host. 
Hence, the question arises: What kind of hospitality do the features of the stop indicate to the rider? In a common stereotype about hospitality, the host invites the guest to "come in, sit down." This comports with what David Sucher calls the main task of city building: "making people comfortable, the same task faced by the host at a party" (2003, p. 20). In other words, it is an invitation to enter a place of shelter and rest. Understood this way, one can see that the implicit message that comes from a stop that has a shelter and a bench is different from one that has only a flag sign and pole stuck into the landscaping (which may or may not be well-maintained). The former stop at least is attempting to approximate the "come in, sit down" message. The latter stop, however, sends a different message, one that implies indifference or even hostility to the rider's comfort.

Now, reflect on the varying messages that the design of stop facilities sends to riders/potential riders with mobility-based disabilities. To someone who uses a mobility device such as a wheelchair, a stop with a concrete pad connected to the surrounding sidewalk network indicates the agency's intention to welcome such riders to the agency's services. The stop with no pad implicitly sends a message that such riders are not accommodated or perhaps even welcome and, rightly or wrongly, sends a message of callousness or indifference by the agency.

Consider the following examples. The first is a bus stop designed for Florence, Italy, by engineers and architects at MIT (Figure 2.1).

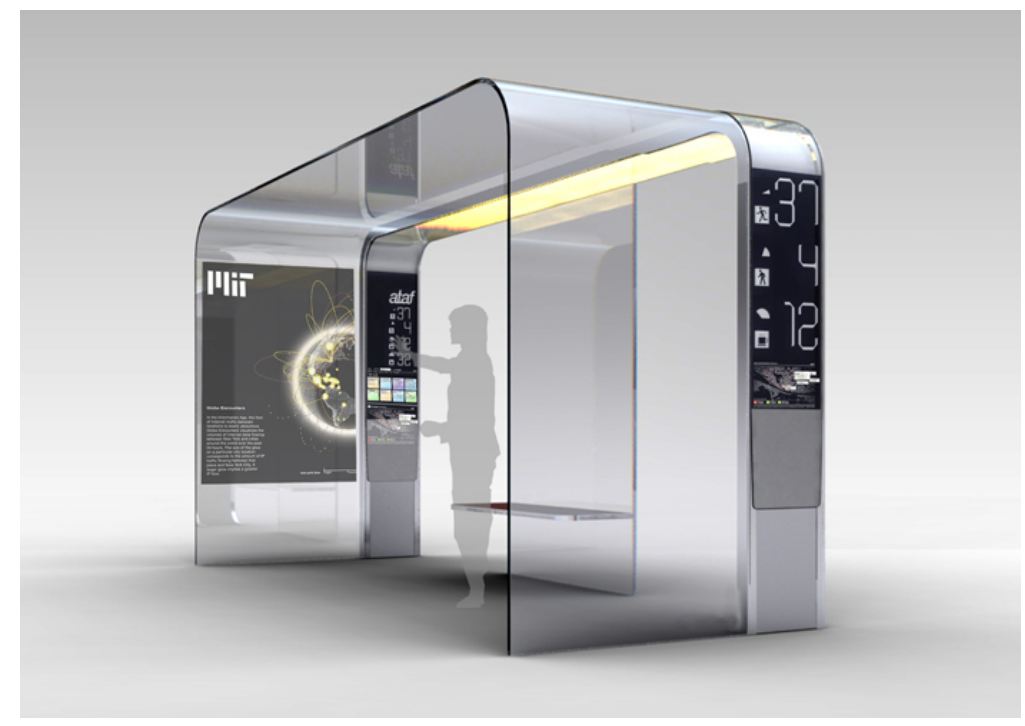

Figure 2.1. An EyeStop bus stop designed by engineers and architects at MIT. Source: My Modern Met.

According to the stop's designers, the facility will provide interactive maps to allow riders to plan their trip, offer digital message boards for neighborhood information, give riders robust connections to the internet, advise riders of their real-time exposure to air pollutants, and "glow at different levels of intensity to signal the distance of an approaching bus" (Yoo, 2009). 
The next stop, located in the Seocho District of Seoul, has a bench that warms up during the winter months and cools down in the summer (SBW, 2018) (Figure 2.2).

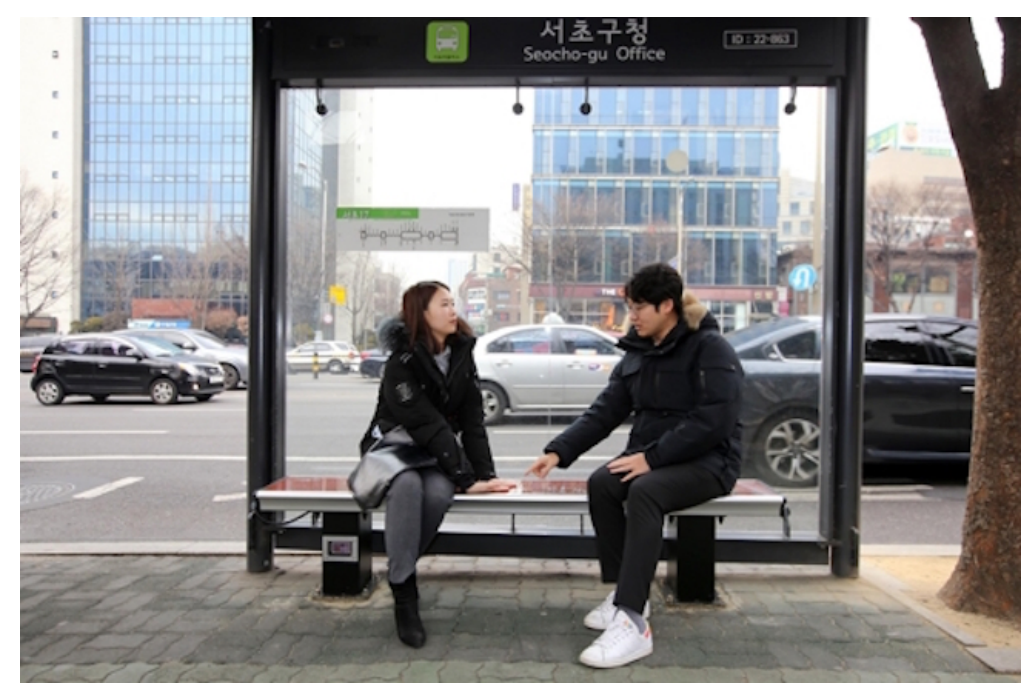

Figure 2.2. A bus stop in the Seocho District of Seoul that has a bench with heating elements to warm riders in winter months and a glass surface to cool with in the summer. Source:The Korea Bizwire.

Contrast these examples with this stop in Pitt Meadows, British Columbia, just outside of Vancouver (Figure 2.3).

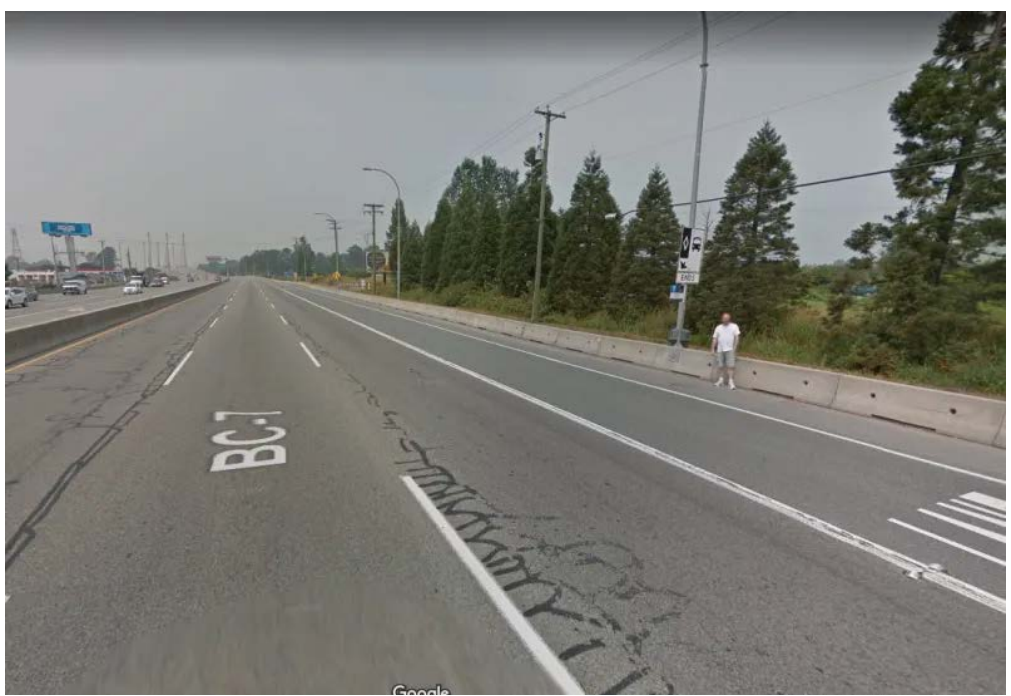

Figure 2.3. The "Sorriest Bus Stop in North America" for 2018, located outside of Vancouver, BC. Source: StreetsBlog USA.

This stop won the dubious distinction of winning the 2018 award for being the "Sorriest Bus Stop in North America" from StreetsBlog USA. According to the StreetsBlog reader 
who submitted the winning entry, the stop is along one of the deadliest roadways in British Columbia (Lougheed Highway). "Transit riders are forced to either a) wait on the other side of the jersey barrier, and then climb over it when the bus arrives, or b) wait on the highway side of barrier, directly exposed to traffic. Riders in wheelchairs must wait on the highway side of the barrier" (Kuntzman, 2018), assuming they can even reach this location.

Granted, the stop in Florence is idealized, highly stylized and, to our knowledge, not yet constructed. Yet, it provides a useful counterfactual representing what off-the-shelf engineering can provide to bus riders, if there was desire and money to provide it. The stop in Seoul, while less grandiose, focuses on creature comfort and sends the implicit message that the transit agency has the rider's backside (literally). The stop in Pitt Meadow, on the other hand, is very real and, sadly, represents a very common condition in North America, judging from the stiff competition it had from the many other sorry bus stops submitted to StreetsBlog. Moreover, the 2018 results follow similar competitions held by StreetsBlog in 2017, 2016, and 2015 (Figures 2.4-2.6).

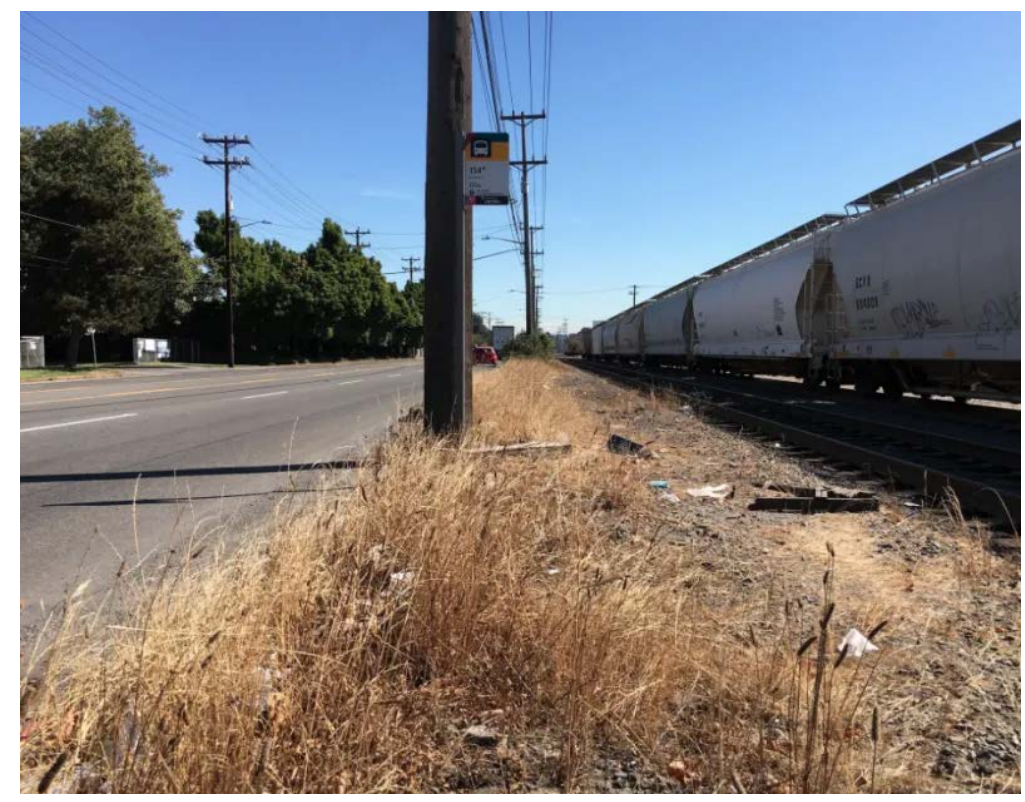

Figure 2.4. The 2027 Sorriest Bus Stop 2017, located in Seattle, WA. Source: StreetsBlog USA. 


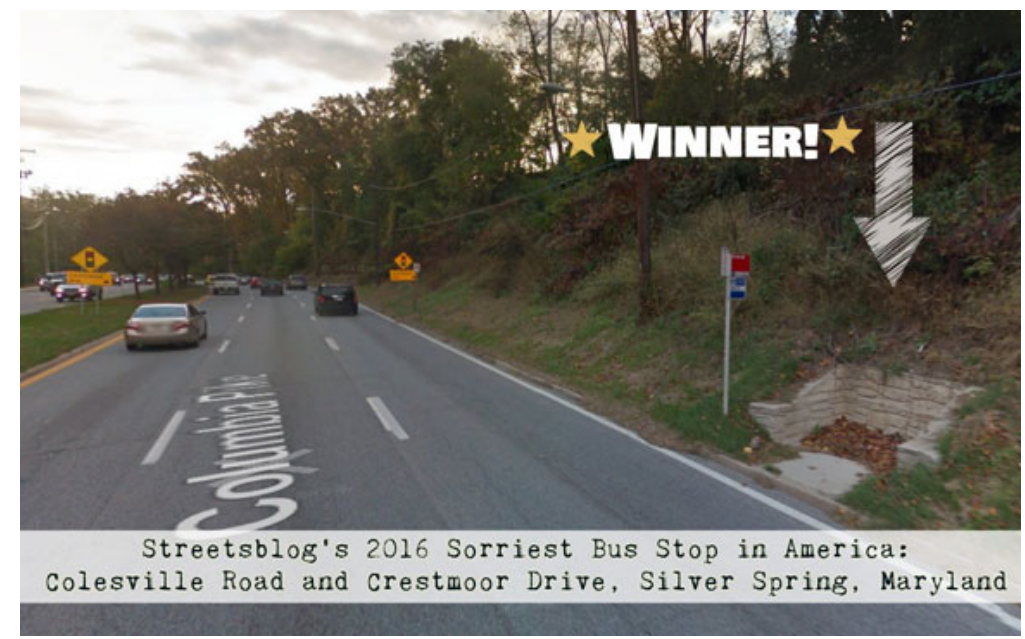

Figure 2.5. The 2016 Sorriest Bus Stop, located in Silver Spring, MD. Source: StreetsBlog USA.

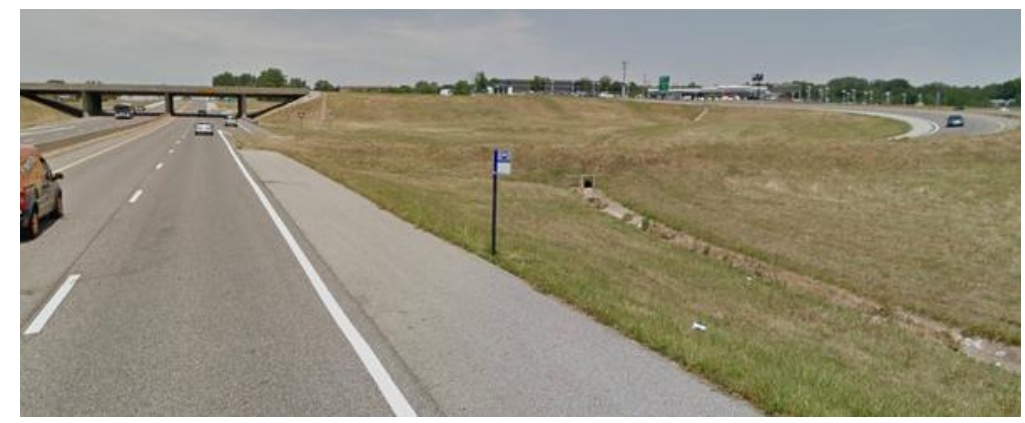

Figure 2.6. The 2015 Sorriest Bus Stop, located in St. Louis, MO. Source: StreetsBlog USA.

Using the point of contact marketing/branding concepts outlined previously, it is reasonable to interpret the stops designed for Florence and Seoul as conveying messages that the transit agency thinks highly of the quality of its service and the value of the rider. On the other hand, the Pitt Meadow stop and the other Sorriest competition winners tend to convey the opposite messages. 


\subsection{AGENCY BUS STOP IMPROVEMENT GUIDELINES}

The most recent statistics from the Federal Transit Administration's National Transit Database indicates that approximately $40 \%$ of all transit trips in the United States are taken on a scheduled-service bus. If one excludes cities with historic rail transit systems such as New York, Chicago, Boston, and Philadelphia, the percentage is more than two-thirds. Given the importance of bus stops both to the physical function of assisting riders with a transition to bus services and to the marketing/branding messages discussed in the previous section, it makes sense that many transit agencies regard the improvement of bus stop features as a priority. The immensity of bus service areas (and hence, the number of bus stops) and the limited capital budgets for most transit agencies, however, make the improvement of all bus stops fiscally improbable. Additionally, there are frequent jurisdictional and legal complications by the fractured nature of ownership and control of the land on which the stops are located, with some situated in public rights-of-way controlled by the state transportation department, others located on city-owned land, and still others sitting on land owned by private surrounding land owners. Each of these owners is likely to have different perspectives on the prospect of having a bus stop on their land as well as varying attitudes about its dimensions and contents.

These challenges have led many transit agencies to develop policy guidance documents to help decision-makers select the bus stops in their systems that will receive facility improvements. The research team collected 27 of these guidance documents to better understand how agencies finesse improvement decision processes. To establish a consistent metric for assessing these 27 documents, researchers began by reviewing the documents from four of the agencies and used that analysis to create a coding system that could be applied to the entire set. One team member then used that framework to conduct an initial coding of the documents, which was then reviewed by other team members for consistency and accuracy. Table 3.1, below, outlines the results of the team's analysis. 
Table 3.1: Inventory of Bus Stop Improvement Placement and Design Guidelines for the Largest U.S. Bus Transit Operators Source: Jensen et al., 2020

\begin{tabular}{|c|c|c|c|c|c|c|c|c|c|c|c|c|c|c|}
\hline & & & & & & & & Decision Making $\mathrm{Fa}$ & ctors Included & $\mathrm{d}$ in Guidelines & & & & \\
\hline City / Agency & $\begin{array}{l}\text { Formal } \\
\text { Guidelines }\end{array}$ & $\begin{array}{l}\text { Publicly } \\
\text { Accessible }\end{array}$ & $\begin{array}{l}\text { Mternative } \\
\text { Document }\end{array}$ & Year Adopted & $\begin{array}{l}\text { TA Installs } \\
\text { Shelters }\end{array}$ & $\begin{array}{l}\text { AD Agency } \\
\text { Installs }\end{array}$ & $\begin{array}{l}\text { Municipality } \\
\text { Installs }\end{array}$ & $\begin{array}{l}\text { ADA (Beyond Basic } \\
\text { Compliance) }\end{array}$ & $\begin{array}{l}\text { Ridership } \\
\text { Thresholds }\end{array}$ & Transfer Points & $\begin{array}{l}\text { Area } \\
\text { Characteris tics }\end{array}$ & $\begin{array}{l}\text { Equity } \\
\text { Concerns }\end{array}$ & $\begin{array}{l}\text { Cus tomer } \\
\text { Requests }\end{array}$ & $\begin{array}{l}\text { Other } \\
\text { Amenities } \\
\text { Installed }\end{array}$ \\
\hline MSP - Metro Transit & 1 & 1 & - & 2018 & 1 & 0 & 0 & 1 & 1 & 1 & 1 & 1 & 2 & 1 \\
\hline Phoenix - Valley Metro & 1 & 1 & - & 2008 & 2 & 0 & 2 & 0 & 1 & 1 & 1 & 0 & 1 & 1 \\
\hline Portland-Trimet & 1 & 1 & - & 2010 & 1 & 2 & 0 & 1 & 1 & 0 & 1 & 0 & 0 & 1 \\
\hline Seattle - King County Metro & 1 & 1 & - & 2018 & 1 & 0 & 0 & 0 & 1 & 0 & 1 & 0 & 0 & 1 \\
\hline Salt Lake City - UTA & 1 & 0 & - & - & 1 & 0 & 2 & 0 & 1 & 1 & 1 & 1 & 0 & 1 \\
\hline LA - Metro \& LADOT & 0 & 0 & 1 & - & 0 & 2 & 2 & - & - & - & - & - & 0 & - \\
\hline NewYork - MTA & 0 & 0 & 1 & - & 0 & 1 & 0 & 0 & 0 & 0 & 0 & 0 & 1 & 1 \\
\hline Chicago - CTA & 1 & 1 & - & 2001 & 1 & 0 & 1 & 1 & 1 & 1 & 0 & 0 & 0 & 1 \\
\hline Washington DC- WMATA & 1 & 1 & - & 2010 & 0 & 2 & 1 & 1 & 1 & 1 & 0 & 0 & 0 & 1 \\
\hline Philad elphia- SEPTA & 1 & 1 & - & 2012 & 0 & 2 & 1 & - & - & - & - & - & 0 & - \\
\hline New Jersey - NJ Transit & 1 & 1 & - & - & 1 & 0 & 0 & 0 & 0 & 0 & 0 & 0 & 0 & 0 \\
\hline Boston - MBTA & 1 & 0 & - & 2018 & - & - & - & - & - & - & - & - & - & - \\
\hline San Francisco-MUNI & 1 & 1 & - & 2017 & 1 & 0 & 1 & 0 & 1 & 0 & 0 & 0 & 0 & 0 \\
\hline Miami-D ade Transit & 1 & 1 & - & 2009 & 0 & 0 & 1 & 0 & 1 & 1 & 0 & 0 & 0 & 1 \\
\hline Atlanta-MARTA & 1 & 1 & - & 2017 & 0 & 1 & 0 & 0 & 1 & 1 & 1 & 1 & 0 & 1 \\
\hline Denver-RTD & 1 & 0 & 1 & 2016 & 1 & 2 & 0 & 0 & 1 & 0 & 0 & 0 & 0 & 1 \\
\hline San Diego - MTS & 0 & 0 & 1 & - & 0 & 1 & 0 & 0 & - & - & - & - & 0 & - \\
\hline Houston - MEtRO & 1 & 1 & - & - & 1 & 0 & 0 & 1 & 1 & 1 & 1 & 0 & 1 & 0 \\
\hline Oakland - ACT ransit & 0 & 0 & 1 & - & 0 & 1 & 0 & - & - & - & - & - & 0 & - \\
\hline B altimore - MTA & 0 & 0 & - & - & 1 & 2 & 0 & 1 & 1 & 1 & 1 & 1 & 0 & 1 \\
\hline Las Vegas - RTC & 0 & 0 & - & - & 1 & - & - & - & - & - & - & - & - & - \\
\hline Pittsburgh - Port Authority & 0 & 0 & - & - & 2 & 0 & 2 & - & 1 & - & - & - & 2 & - \\
\hline Orange County - OCTA & 1 & 1 & - & 2014 & 0 & 0 & 1 & 1 & 1 & 1 & 1 & 0 & 0 & 1 \\
\hline San Antonio - VIA & 1 & 1 & - & - & 1 & 0 & 0 & 0 & 1 & 0 & 1 & 0 & 0 & 1 \\
\hline Dallas - DART & 0 & 0 & 1 & - & 1 & 0 & 0 & 0 & 1 & 0 & 0 & 0 & 0 & 1 \\
\hline Milwaukee - MCTS & 1 & 0 & - & 2018 & 2 & 2 & 2 & 0 & 1 & 0 & 0 & 0 & 1 & 1 \\
\hline Cleveland - GCRTA & 1 & 1 & - & 2018 & 1 & 0 & 0 & 0 & 1 & 0 & 0 & 0 & 0 & 1 \\
\hline San Jose - VTA & 1 & 1 & - & 2016 & 1 & 0 & 0 & 0 & 1 & 0 & 1 & 0 & 0 & 1 \\
\hline Chicago - PACE & 1 & 1 & - & - & 2 & 2 & 0 & 0 & 1 & 0 & 1 & 0 & 1 & 1 \\
\hline Key: $0=$ No, $1=$ Yes, 2 & $s,-=$ & nt & & & & & & & & & & & & \\
\hline
\end{tabular}

As outlined in Table 3.1, all 27 of the agencies' documents delineated responsibilities for stop placement and management among the three stakeholder groups-the transit agency, the local government, or an ad agency. In slightly more than half of the documents (15) these responsibilities fell solely on the transit agency, while approximately one-quarter of the documents assigned sole responsibility to the local government. Only four designated an ad agency as the sole party responsible.

Most all of the documents articulated the range of stop features available, plus criteria for placing those features at bus stop sites. While a handful of the documents directly addressed site design issues, most focused on policies and procedures.

Virtually all of the guidance documents articulated criteria for selecting stops for improvements, frequently relying on pre-existing stop-level boardings as a primary criterion. Documents for Dallas, Seattle, and Cleveland, for example, all set a minimum threshold of at least 50 boardings per day to justify improving a stop. These guidelines, thus, implicitly reflect a causal understanding of ridership resulting in stop improvements rather than the other way around (i.e., using stop improvements to help build and facilitate higher ridership). In fact, only one document, from Santa Clara, CA, included increasing ridership as a motivation for improving stops. Other factors reflected across the range of the 27 documents include ADA considerations, whether a stop is a transfer point between several transit lines, development characteristics of the neighborhood 
surrounding a stop (with a particular emphasis on development density), social equity considerations, the presence of seniors, and rider complaints and requests.

Through the research team's review of these 27 documents, team members were able to identify a set of recurring themes that could serve as the basis for articulating a statement on current best practices among U.S. transit agencies. Consistent with the findings of Buchanan and Hovenkotter (2018) and Boyle (2015), the documents the research team reviewed emphasized (1) defining responsibilities for making and implementing improvement decisions and maintenance; (2) articulating clear and objective standards for improvement decisions that minimize potential biases (dis)favoring certain areas; and (3) establishing processes for creating data-sourced, long-range improvement plans that allow for incremental implementation as financial resources become available. 


\subsection{QUANTITATIVE LINKS BETWEEN STOP IMPROVEMENTS AND RIDERSHIP DEMAND}

As outlined in the previous section, improving bus stop facilities is a priority with many transit agencies. Unsurprisingly, it is also popular with riders. In its 2016 national survey of U.S. bus riders, the Transit Center reported that upgrading bus stop facilities ranked within the top four preferences for improving bus transit nationwide (Higashide \& Accuardi, 2016). Consistent with other measures of rider preferences (e.g., Higashide \& Buchanan, 2019), respondents to the survey ranked increasing service frequency and service hours higher than improving bus stops. However, bus stop facility improvements beat out other options that are sometimes popular with political leaders, such as providing Wi-Fi.

For persons with mobility limitations, conditions at the bus stop are even more important. In their nationwide survey of 1,927 persons with mobility-related disabilities, Thatcher et al. (2013) determined that the nature of the physical environment within the street right-of-way was the primary impediment keeping persons who want to ride scheduled-bus service from actually doing so. The nature of the survey question did not focus on bus stop facilities, per se, focusing instead on the entirety of the street environment. This means that the results likely include responses targeting features other than the nature of the bus stop, such as the presence and condition of sidewalks, curb ramps, and street crossings. Still, bus stops are included in the measure.

Moreover, the results from the survey emphasize the (rather obvious) need to assess the entirety of the physical environment between the front door of the building to or from which the rider is traveling and the interior of the bus vehicle.

Given the popularity of making bus stop improvements with transit decision-makers and bus riders, and the importance of making such improvements to riders with mobilityrelated disabilities, one would expect that making such improvements would result in increased ridership demand. Interestingly, there is very little literature addressing this question.

Brown et al. (2006), in their assessment of bus stop conditions in the Triangle Research area of North Carolina, developed a "bus stop index" calibrated to variations in the physical features of different bus stops and then compared that index to ridership, finding that a one-unit increase in the index reflected a 31\% ridership increase. The strength of the study's conclusions was limited by the use of rider survey data for calculating demand and a general lack of controls of possible confounding influences, a limitation also found in Talbott's (2011) assessment of stop features and ridership in Greensboro, Kansas City, and Seattle.

More recent work has focused on the intuitive connection between bus stop shelters and ridership in the context of extreme weather. Prior research demonstrates the general principle that ridership tends to vary with weather extremities (see Guo et al., 2007; Stover \& McCormack, 2012). Given this, one would naturally expect that shelters would make a difference in mitigating those demand variations on days that were either 
extremely rainy, snowy, or hot; the studies that have looked at these associations have confirmed this intuitive assumption. In their assessment of shelters in Salt Lake City and Chicago, Miao et al. (2016) found that ridership levels at Salt Lake stops with shelters saw less impact on days with heavy precipitation or extreme heat than stops without shelters. The Chicago data, however, were less conclusive.

Another area of research born of intuitive experience relates to people's sense of impatience, particularly while waiting for transit. Sourced in the concept that one's perception of time passing varies according to a number of factors-including attention distraction, personal anxiety, and positive or negative external conditions-it is wellestablished that people waiting for transit perceive time moving more slowly than when they are in-vehicle and traveling toward their destination (Meng, Rau \& Mahardhika, 2018). That sense of slowed time while waiting for a bus or train is a negative component associated with the transit experience. The fact that respondents to the 2016 Transit Center survey listed service frequency as their highest-ranked recommendation for transit improvements underscores just how much people hate to wait for transit. "Waiting is everyone's least favorite phase of a trip. It's governed mostly by frequency and reliability, but of course the quality of the waiting environment has a big impact" on how we perceive time passing (Walker, 2012, p. 81). It would stand to reason that exposed or uncomfortable conditions at bus stops may have an exacerbating effect on this phenomenon. In their research on this issue, Fan, Guthrie, and Levinson (2016) found that riders' perceived passage of time waiting at stops with shelters and benches was significantly less than those waiting at stops without those features. These findings ratify what most bus riders can tell you: making people more comfortable and protected from the elements reduces some of the negative elements connected with waiting for the bus.

As sparse as the literature is on the ridership impacts associated with bus stop features, there are even fewer studies assessing the importance of stop features for riders with mobility-related disabilities. Most of those that do exist are focused on developing strategies for upgrading stop features to optimize them for existing populations of riders who qualify for paratransit services under the Americans with Disabilities Act (ADA) (e.g., Wu, Gan, Cevallo, \& Shen, 2011). In other words, according to these studies, stop improvements are tied to the existence of a concentration of ADA paratransit patrons nearby. One of the few studies to look at whether making stop improvements has an impact on ridership by mobility-limited riders is Thatcher et al.'s (2013) assessment, noted above, which includes data on the rates of bus ramp/lift deployments in Olympia, WA, and Portland, OR, both before and after a series of stops had been improved to make them ADA compliant. In the case of Portland, ramp deployments at the improved stops doubled, while in the quarter-mile area around the stops, demand for ADA paratransit by those who conditionally qualify for that service declined $12 \%$. In Olympia, the use of lifts to access scheduled service buses increased $37 \%$ at the improved stops, compared to $16 \%$ system-wide. Neither of these assessments, however, employed control groups or otherwise attempted to account for other possible explanations for the variations. 
Given the popularity of bus stop improvements with decision-makers and riders, but the relative lack of published research on the topic, our team set out to determine whether, and to what degree, improving bus stop facilities is associated with quantitative changes in ridership demand. Our investigations, so far, have involved three separate phases, each with an increasing level of statistical rigor.

\subsection{PHASE I: DESCRIPTIVE DATA ANALYSIS}

Our first investigation focused on possible ridership changes in discreet corridors in the Salt Lake City region where the Utah Transit Authority (UTA) had systematically improved a set of contiguous bus stops along a single route over a short time period (i.e., using the corridor-based improvement strategy referenced in the intro to this report).

We began first with the stops along UTA's number 41 bus line. In 2014, UTA upgraded most stops along the 41's route-3900/4100 South—between Meadowbrook Station and Redwood Road (Figure 4.1). The upgrades included creating ADA-compliant concrete pads, connecting those pads to surrounding sidewalk networks, and installing a variety of fixtures, including trash cans, benches, shelters, and (at a grocery store) a shopping cart corral (Figure 4.2). Our objective was to analyze stop-level boarding data along this corridor to determine whether, and the degree to which, the investments might be associated with changes in both stop-level boardings and demand for ADA paratransit.

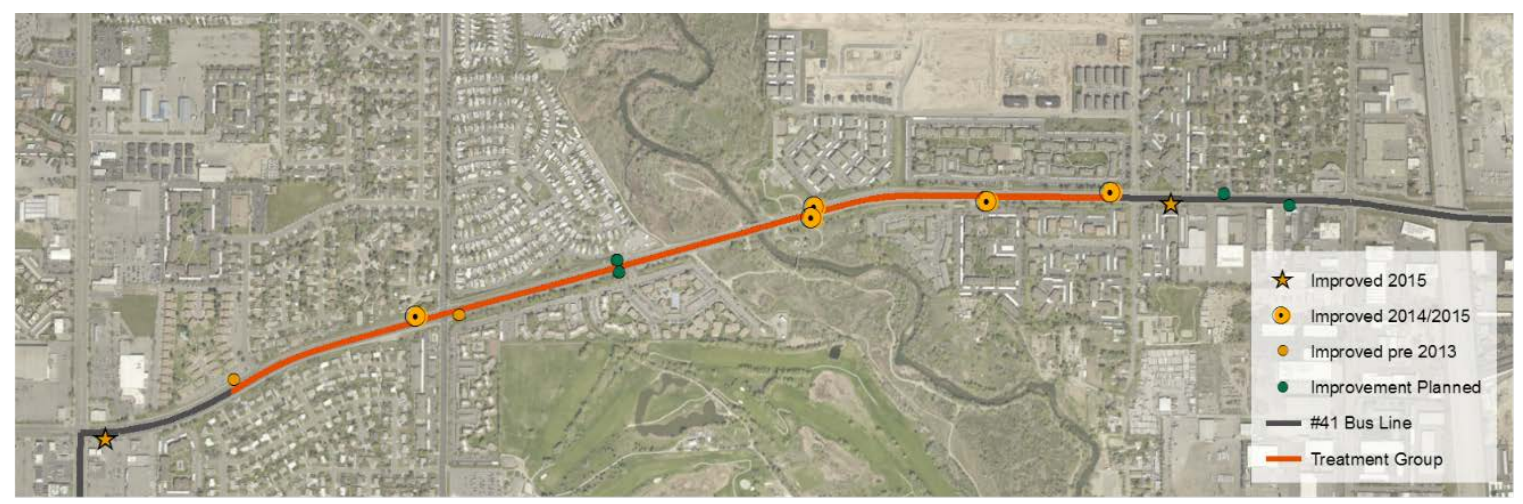

Figure 4.1. Bus stop improvement sites along the \#41 bus line. 

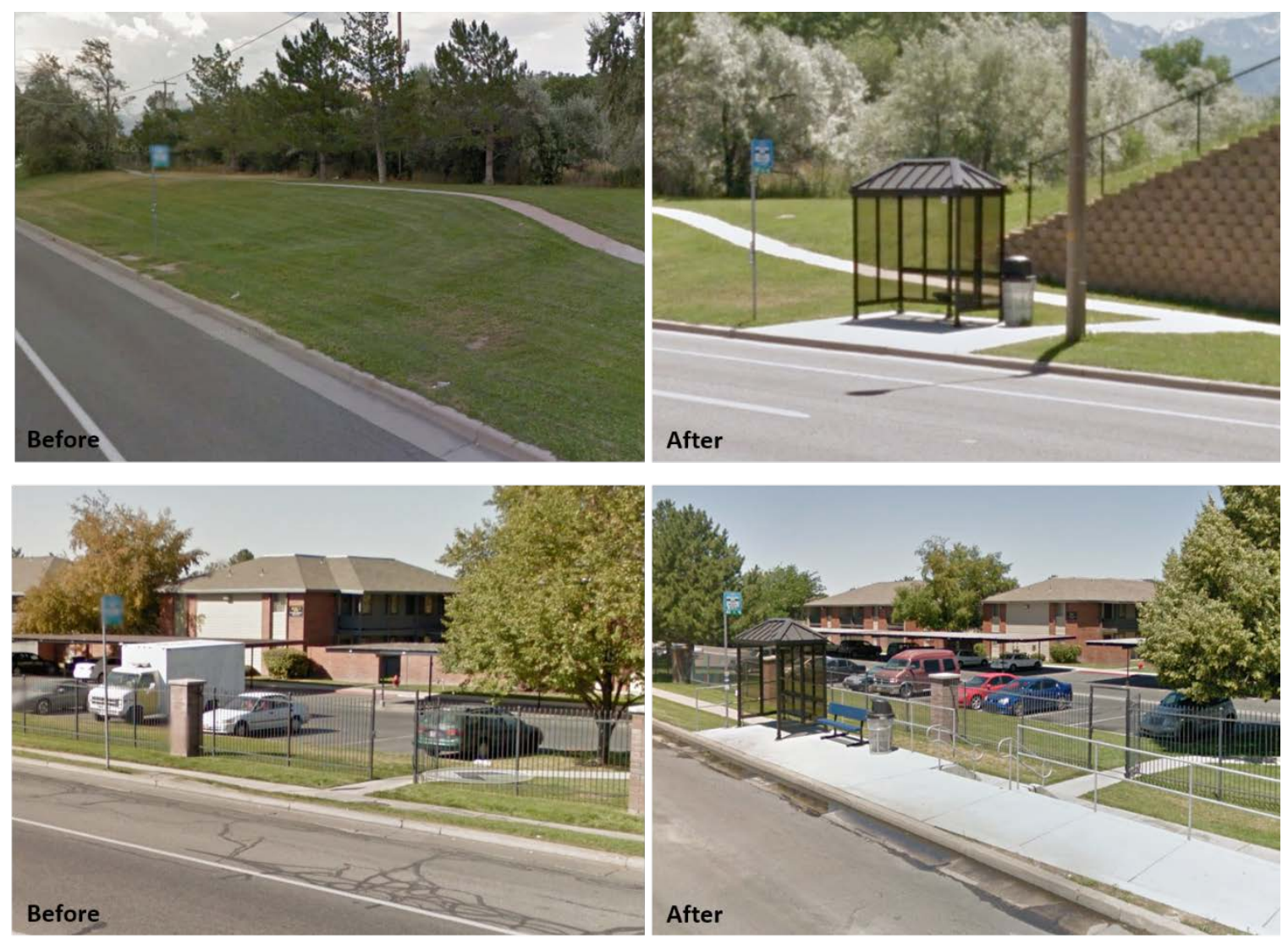

Figure 4.2. Before and after bus stop facility improvements along the \#41 bus line.

For this preliminary stage of the project, we compared ridership and paratransit data from before and after the improvements for the stops that were improved (i.e., the treatment group) with stops further along the \#41 route that were not improved (i.e., the control group) (Figure 4.3).

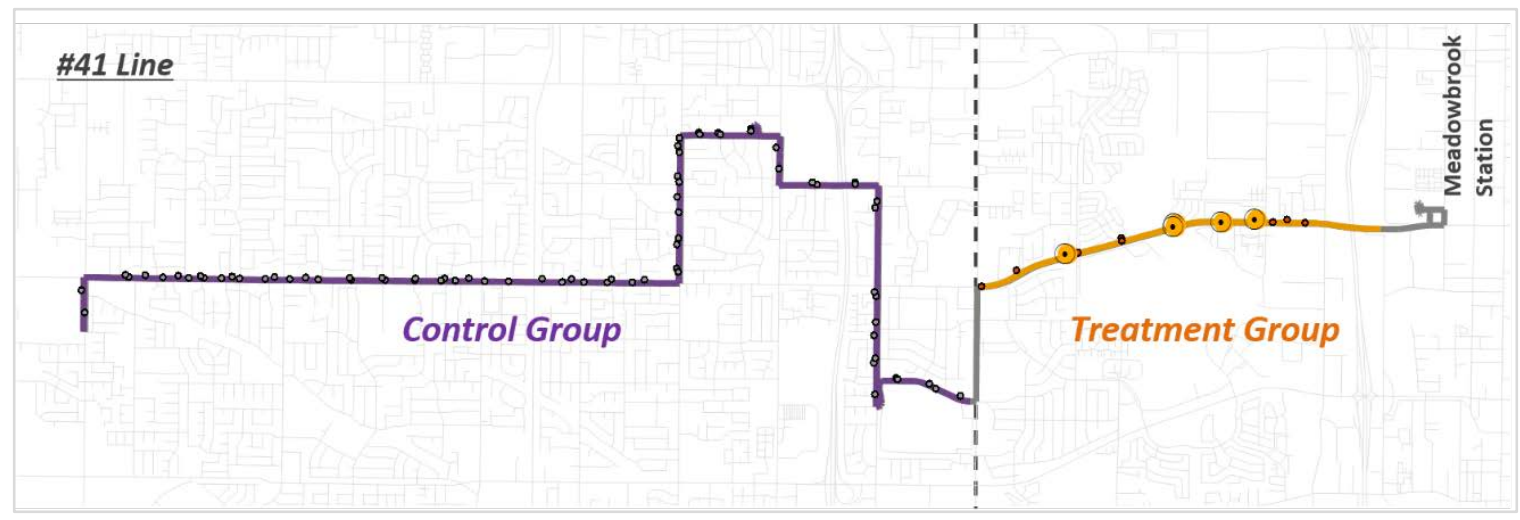

Figure 4.3. The treatment and control group sections of the \#41 bus line. 
UTA constructed all of the treatment group improvements during the month of December 2014. We, consequently, used ridership data from the six-month period of January through June 2014 as the "before" data. For the "after" period, we used data from the same six-month period of 2015 , recognizing that this might be too early to capture the full impact if there was a lag in customer responses to the improvements. To assess ridership of the regular scheduled-bus service, the team assessed stop-level boardings at each stop for both the treatment and control group stops. For possible impacts on ADA paratransit demand, the team geocoded all paratransit deployment locations (i.e., the origins of individual riders' trips) and selected those trips that began within a network quarter-mile buffer (i.e., along public streets rather than as the crow flies) surrounding both the treatment group and control group stops.

Our analysis revealed that the sum of the scheduled-service boardings for treatment group stops was 5.9\% higher in the after period than it was for the before period (Figure 4.4). Boardings at stops in the control group, by contrast, showed only a $1.7 \%$ overall increase in ridership between the same periods. Meanwhile, the team observed that paratransit deployments in the buffer areas around the control group stops decreased by $9 \%$ between the before and after periods, while they increased by $28.4 \%$ for the areas surrounding the control group stops (Figure 4.5).

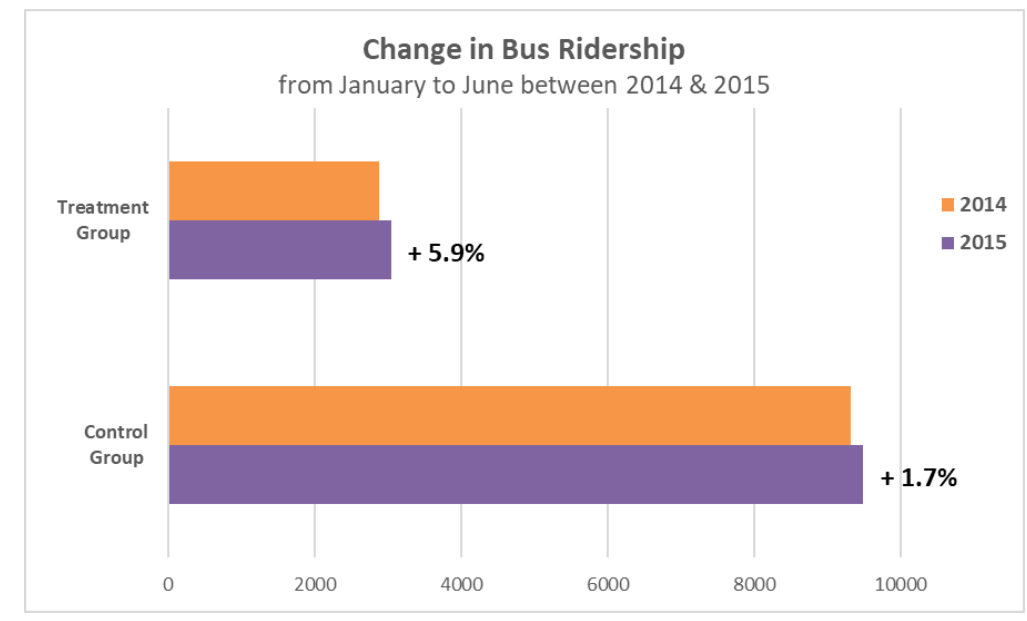

Figure 4.4. January-June bus boardings along the \#41 bus line in 2014 and 2015. 


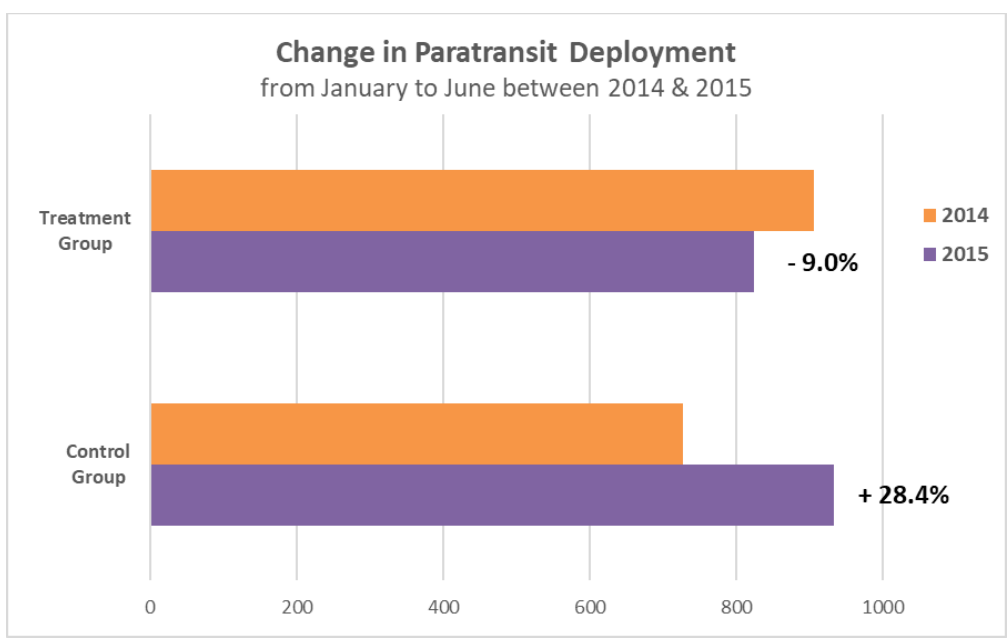

Figure 4.5. January-June ADA paratransit pick-ups along the \#41 bus line in 2014 and 2015.

The magnitude of the ADA paratransit results suggested that there was perhaps a problem with the data, so we elected to compare our results to the trend in paratransit deployments for the entire UTA service area for the January through June periods from 2013 to 2016 (Figure 4.6). While the overall trend was up, there was a slightly downward change of $0.3 \%$ in 2015 compared to 2014 . This suggests the $28.4 \%$ increase for our control group during the same period was anomalous and tended to confirm our suspicions about our data, particularly for the control group stops. Even if the control group data were anomalous, the $9 \%$ decrease in demand for the treatment group was still notable when compared to the regional trend of $-0.3 \%$.

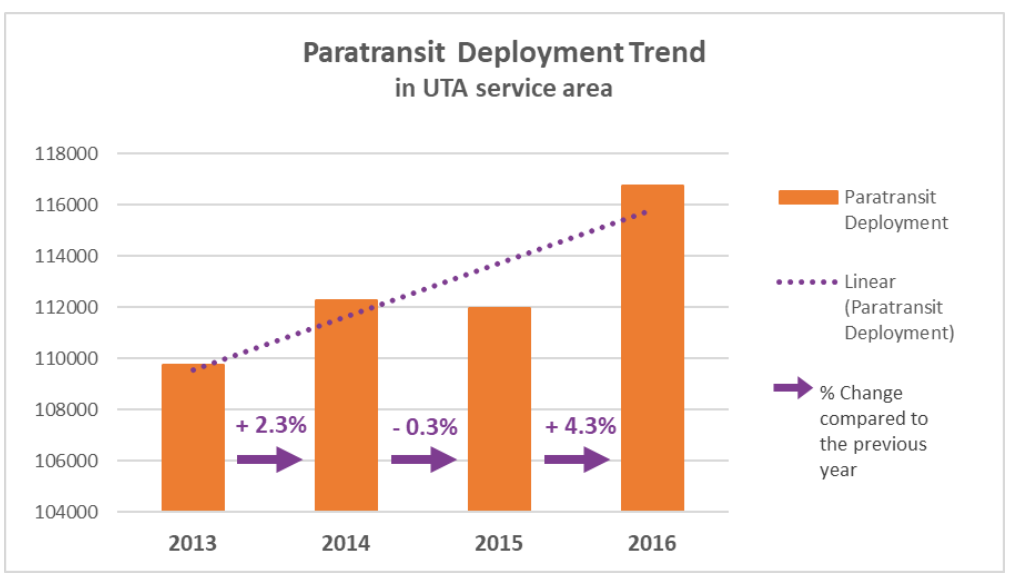

Figure 4.6. ADA paratransit deployment trend in entire UTA service area, 2013-2016.

Possible anomalies aside, the lack of statistical controls for potential confounding variables made the results, while interesting, of limited use. Still, the purpose of this first "proof of concept" phase was to evaluate whether there might be something connecting 
stop improvements with changes in demand that would be worth further study. The team concluded that there was.

\subsection{PHASE II: PROPENSITY SCORE MATCHING}

The team's first step toward greater statistical rigor employed an analytical technique called propensity score matching (PSM). In PSM, researchers create a control group by selecting a group of cases from the study's data pool that have not been subjected to the treatment being studied, but otherwise share characteristics similar to the cases in the treatment group. The key to the selection process is to focus on features that may be associated with confounding variables (i.e., characteristics that could provide an alternative explanation for the outcome results identified later in the analysis). Once the control group is selected using this technique, the study can proceed with quasi "applesto-apples" comparisons between the control and treatment groups, where the primary thing that varies between them is the treatment (Rosenbaum \& Rubin, 1983).

"Propensity score" refers to a single value assigned to each case reflecting its propensity to be like other cases in the data pool. Once assigned, each case in the treatment group is matched with a case in the control group, based on the propensity score. Once matched, researchers compare the average difference in outcome variables before and after application of the treatment under study between the control and treatment groups. This comparison of before-and-after periods between the two groups shows the possible impacts of the treatment (Leite, 2017). Using PSM thus effectively controls for selection bias (Dehejia \& Wahba, 2002) and creates conditions that functionally resemble those of a randomized experiment (D'Agostino, 1998).

Since its introduction in 1983, PSM has been employed with increasing frequency in social science, medical, and public health research contexts, but not as frequently in planning contexts. One of the early planning examples comes from a Cao, Xu, and Fan (2010) study where the researchers used PSM to control for possible self-selection bias in an analysis of residential location and driving patterns. Cao and Schoner (2014) also used PSM to observe possible transit ridership impacts arising from the construction of a new light rail line. Other planning-related PSM applications include those by Sutton (2014), Talen (2014), Ewing (2015), Park et al. (2018), Deng and Yan (2019), Zandiatashbar et al. (2019), and Kim et al. (2020). This is a short history-covering only a decade-but the technique's use is evidently increasing.

Translating the PSM methodology to this project, the research team expanded their geographic scope from route \#41's single corridor used in the initial phase of the study to include all bus stops in Salt Lake County, the central county in the UTA service area. Within this expanded area, the team identified 30 stops (including those along the \#41) that UTA had improved between 2014 and 2016, plus a total of 2,221 stops that at the time of the data collection (2017) had not been improved.

The team then identified 18 characteristics (Table 4.1) that, based on the team's reading of relevant literature, could influence the outcome measures we planned to assess-changes in scheduled-service bus boardings and demand for ADA 
paratransit—and hence could bias the results (Dill et al., 2013; Ewing et al., 2015). These characteristics can be conceptually classified into three primary categories: demographics (10), land use (5), and regional accessibility (3). The land use characteristics follow the now popular five-D alliterative formulation of development Density, land use Diversity, street Design, Destination accessibility, and Distance to transit (see, e.g., Ewing \& Cervero, 2010).

Table 4.1: Variable Description for Phase II

\begin{tabular}{|c|c|c|}
\hline Variables & Description & Sources \\
\hline \multicolumn{3}{|l|}{ Outcome Variables } \\
\hline Change in Bus Ridership & $\begin{array}{l}\text { Change of annual bus ridership at a stop between } 2013 \\
\text { and } 2016\end{array}$ & UTA \\
\hline $\begin{array}{l}\text { Change in Paratransit } \\
\text { Demand }\end{array}$ & $\begin{array}{l}\text { Change of annual paratransit demand within a 1/4-mile } \\
\text { network buffer around a stop between } 2013 \text { and } 2016\end{array}$ & UTA \\
\hline \multicolumn{3}{|c|}{ Control Variables for Propensity Score Matching } \\
\hline Total Household & Total household within a $1 / 2$-mile buffer around a stop & ACS 2011-2015 \\
\hline Household Size & $\begin{array}{l}\text { Average household size within a } 1 / 2 \text {-mile buffer around a } \\
\text { stop }\end{array}$ & ACS 2011-15 \\
\hline $\begin{array}{l}\text { \% Non-Hispanic White } \\
\text { Population }\end{array}$ & $\begin{array}{l}\text { Percentage of non-Hispanic white population within a } 1 / 2- \\
\text { mile buffer around a stop }\end{array}$ & ACS 2011-15 \\
\hline $\begin{array}{l}\% \text { Population } 65 \text { years } \\
\text { and over }\end{array}$ & $\begin{array}{l}\text { Percentage of population } 65 \text { years and over within a 1/2- } \\
\text { mile buffer around a stop }\end{array}$ & ACS 2011-15 \\
\hline $\begin{array}{l}\text { \% Household Living } \\
\text { Alone }\end{array}$ & $\begin{array}{l}\text { Percentage of household living alone within a } 1 / 2 \text {-mile } \\
\text { buffer around a stop }\end{array}$ & ACS 2011-15 \\
\hline \% Students in College & $\begin{array}{l}\text { Percentage of students in college and grad school within } \\
\text { a } 1 / 2 \text {-mile buffer around a stop }\end{array}$ & ACS 2011-15 \\
\hline $\begin{array}{l}\text { Median Household } \\
\text { Income }\end{array}$ & $\begin{array}{l}\text { Median household income in the past } 12 \text { months within } \\
\mathrm{a}^{1 / 2} \text {-mile buffer around a stop }\end{array}$ & ACS 2011-15 \\
\hline $\begin{array}{l}\text { \% Population Annual } \mathrm{HH} \\
\text { Income below Poverty }\end{array}$ & $\begin{array}{l}\text { Percentage of population with annual household income } \\
\text { below poverty level within a } 1 / 2 \text {-mile buffer around a stop }\end{array}$ & ACS 2011-15 \\
\hline $\begin{array}{l}\text { \% Renter-Occupied } \\
\text { Household }\end{array}$ & $\begin{array}{l}\text { Percentage of renter-occupied household within a 1/2- } \\
\text { mile buffer around a stop }\end{array}$ & ACS 2011-15 \\
\hline $\begin{array}{l}\% \text { Household without } \\
\text { Vehicle Available }\end{array}$ & $\begin{array}{l}\text { Percentage of household with no vehicle available within } \\
\text { a } 1 / 2 \text {-mile buffer around a stop }\end{array}$ & ACS 2011-15 \\
\hline Activity Densitya & $\begin{array}{l}\text { Activity density within a } 1 / 2 \text {-mile buffer around a stop } \\
\text { population + employment/gross land area in a sq. mile }\end{array}$ & $\begin{array}{l}\text { ACS 2011-15; } \\
2013 \text { LEHD }\end{array}$ \\
\hline Job Population Balance ${ }^{a}$ & $\begin{array}{l}\text { Job-pop. balance within a } 1 / 2 \text {-mile buffer around a stop } \\
1-\left[\text { ABS(employment }-0.2^{*} \text { population }\right) /(\text { employment }+ \\
0.2^{*} \text { population)] }\end{array}$ & $\begin{array}{l}\text { ACS 2011-15; } \\
2013 \text { LEHD }\end{array}$ \\
\hline Entropy & $\begin{array}{l}\text { Land use mix within a } 1 / 2 \text {-mile buffer around a stop } \\
\text { Entropy= -[residential share* In(residential share)+ } \\
\text { commercial share*In(commercial share)+ public } \\
\text { share*In(public share)]/In(3) }\end{array}$ & $\begin{array}{l}\text { WFRC; Tax } \\
\text { Ass'rs data }\end{array}$ \\
\hline$\%$ of 4 -Way Intersection & $\begin{array}{l}\text { Percentage of four-way intersections within a 1/2-mile } \\
\text { buffer around a stop }\end{array}$ & TomTom \\
\hline Transit Stop Density & $\begin{array}{l}\text { Number of transit stops within a } 1 / 2 \text {-mile buffer around a } \\
\text { stop }\end{array}$ & AGRC \\
\hline
\end{tabular}




\begin{tabular}{lll}
\hline $\begin{array}{l}\text { \% Regional Destination in } \\
20 \text { minutes by Car }\end{array}$ & $\begin{array}{l}\text { Percentage of regional employment within 20 minutes } \\
\text { by car in a TAZ where a stop is located. }\end{array}$ & $\begin{array}{l}\text { 2010 } \\
\text { Census; } \\
\text { 2013 LEHD }\end{array}$ \\
\hline $\begin{array}{l}\text { \% Regional Destination in } \\
30 \text { minutes by Transit }\end{array}$ & $\begin{array}{l}\text { Percentage of regional employment within 30 minutes } \\
\text { by transit in a TAZ where a stop is located. }\end{array}$ & $\begin{array}{l}2010 \\
\text { Census; }\end{array}$ \\
\hline Bus Ridership in 2013 & Total number of stop-level bus ridership in 2013 & UTA
\end{tabular}

a In the calculation, population is the total number of people and employment is the total number of jobs.

Armed with these 18 characteristics (now instrumented as variables), the team used ttests to quantify differences between all of the 2,251 stops. Using a binary logistic regression model, the team estimated the propensity score for each stop, which functionally assessed the probability of any stop receiving the improvements we were studying. The matching part of the process involved finding unimproved stops that had statistically similar propensity scores to stops that had been improved. The former became our control group, while the latter served as our treatment group. The results of these analyses are displayed in Table 4.2 and Figure 4.7, below. For more information on the team's analytical procedures, see Kim et al. (2020).

Table 4.2: Mean Differences Between Improved and Unimproved Salt Lake County Bus Stops for Observed Covariates

\begin{tabular}{|c|c|c|c|c|c|c|}
\hline \multirow[b]{2}{*}{ Variables } & \multicolumn{3}{|c|}{ Before Matching (Mean) } & \multicolumn{3}{|c|}{ After Matching (Mean) } \\
\hline & $\begin{array}{c}\text { Stops } \\
\text { Improved } \\
2014-16\end{array}$ & $\begin{array}{c}\text { Un- } \\
\text { Improved } \\
\text { Stops }\end{array}$ & $\begin{array}{l}\text { Mean } \\
\text { Diff. }\end{array}$ & $\begin{array}{c}\text { Stops } \\
\text { Improved } \\
2014-16\end{array}$ & $\begin{array}{l}\text { Un- } \\
\text { Improved } \\
\text { Stops }\end{array}$ & $\begin{array}{c}\text { Mean } \\
\text { Diff. }\end{array}$ \\
\hline Total Household & 2,083 & 1,705 & $378^{*}$ & 2,130 & 1,976 & 154 \\
\hline Household Size & 2.36 & 2.82 & $-0.47^{\star \star \star}$ & 2.49 & 2.41 & 0.08 \\
\hline \% Non-Hispanic White & 60.95 & 68.94 & $-7.99^{\star \star}$ & 59.23 & 63.68 & -4.45 \\
\hline \% Population $65+$ years & 9.19 & 10.88 & $-1.69^{\star \star}$ & 8.69 & 9.67 & -0.98 \\
\hline \% Household Living Alone & 43.55 & 29.55 & $14.00^{\star \star \star}$ & 39.18 & 39.81 & -0.62 \\
\hline \% Students in College & 13.45 & 10.65 & $2.81^{*}$ & 12.99 & 11.77 & 1.22 \\
\hline Median Household Income & 39,910 & 55,185 & $-15,275^{\star \star \star}$ & 40,982 & 45,645 & $-4,663$ \\
\hline \% Population Below Poverty & 24.46 & 16.80 & $7.66^{\star \star \star}$ & 24.01 & 21.92 & 2.09 \\
\hline \% Renter-Occupied HH & 69.13 & 44.33 & $24.80^{\star \star \star}$ & 65.36 & 63.53 & 1.84 \\
\hline$\% 0$ Vehicle Household & 16.44 & 8.32 & $8.11^{\star \star \star}$ & 14.05 & 13.69 & 0.36 \\
\hline Activity Density & 15,082 & 8,357 & $6,724^{\star \star \star}$ & 13,701 & 13,569 & 132 \\
\hline Job Population Balance & 0.29 & 0.55 & $-0.26^{\star \star \star}$ & 0.32 & 0.34 & -0.02 \\
\hline Entropy & 0.83 & 0.69 & $0.14^{\star \star \star}$ & 0.83 & 0.78 & 0.05 \\
\hline$\%$ of 4-Way Intersection & 0.39 & 0.27 & $0.12^{\star \star \star}$ & 0.37 & 0.38 & -0.01 \\
\hline Transit Stop Density & 38.63 & 25.32 & $13.31^{\star \star \star}$ & 35.46 & 33.88 & 1.58 \\
\hline \% Destination 20 mins. Car & 56.31 & 54.62 & $1.69 * *$ & 56.41 & 56.79 & -0.38 \\
\hline \% Destination 30 mins. Transit & 24.66 & 19.83 & $4.83^{\star \star \star}$ & 23.98 & 66.94 & -42.96 \\
\hline Bus Ridership in 2013 & 1,880 & 1,177 & 703 & 1,852 & 1,103 & 748 \\
\hline Number of Bus Stops & 30 & 2,221 & & 24 & 24 & \\
\hline
\end{tabular}

***: $p<.01, * *: p<.05, *: p<.1$ (independent t-test results) 


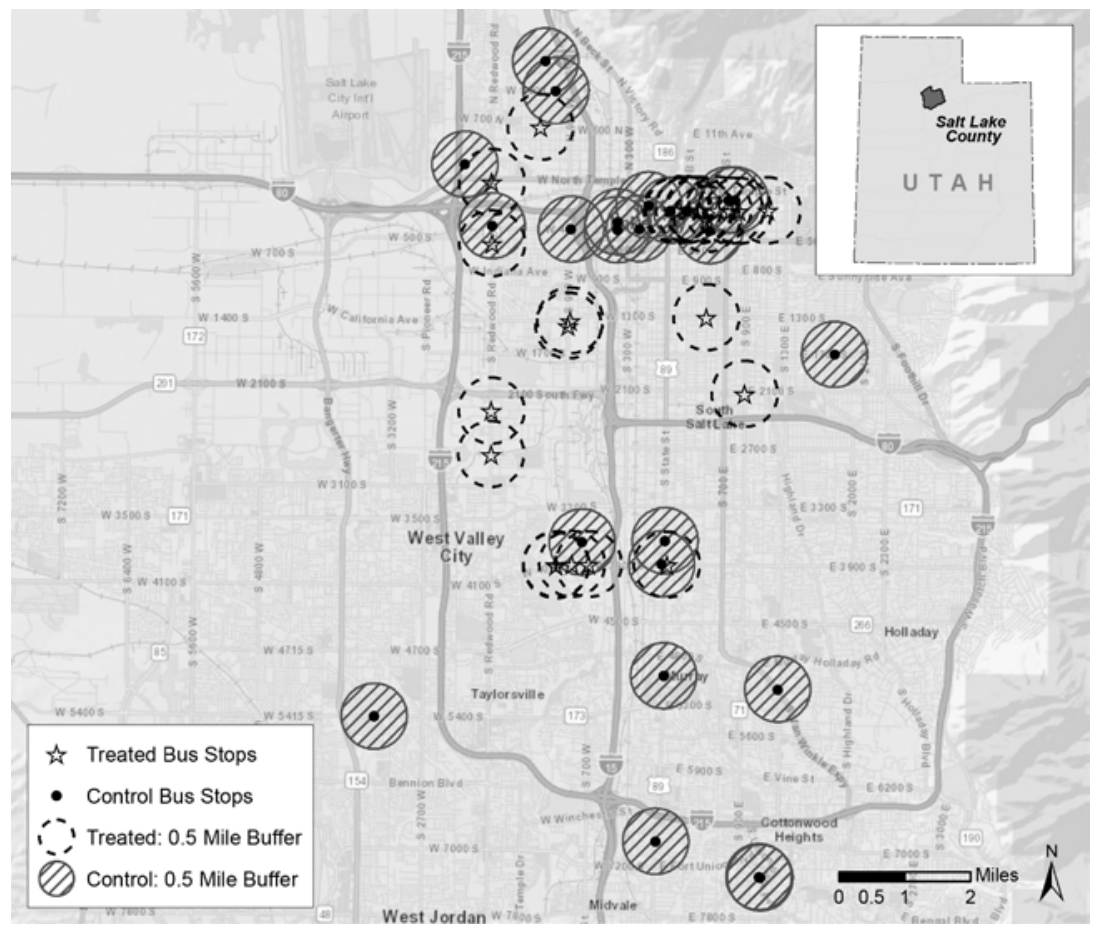

Figure 4.7. Locations of the Salt Lake County bus stops matched using propensity scores.

As Table 4.2 indicates, of the 30 stops that UTA improved during the timeframe of the study, the research team was able to match 24 to 24 unimproved stops. Once matched, the team could estimate the effect of the stop improvements on the boardings associated with the 24 improved stops.

But first the team had to acquire UTA ridership data. Because work on the improved stops occurred during the construction seasons of 2014 and 2015, the team obtained data for the 12-month period of March 1, 2013, to February 28, 2014, for the before period and the same 12-month window in 2016-17 for the after period. To measure the number of boardings on scheduled-service buses, the team relied on data from automated passenger counter sensors that are installed on all UTA buses. For ADA paratransit, the team relied on geocoded location pick-up data, selecting those trips beginning within a quarter-mile network buffer around each stop.

Focusing on data for the treatment and control group stops, the team used the difference in mean change between the treatment and control group stops for the before-and-after time periods. This generated an average treatment effect (ATE) for both the rate of stop-level boardings onto scheduled-service buses and the deployment rate for ADA paratransit services. The analysis showed that annual scheduled-service boardings at the unimproved stops increased from the before to the after periods by an average of 2,260 (column B of Table 4.3). The improved stops saw an increase, too, but their average increase was 5,453 (column A)-141\% more than that of the unimproved stops. In other words, during the after time period, improved stops had an average of 
3,193 more boardings than unimproved stops, a difference that was statistically significant at the 0.05 level. Paratransit demand in the buffer areas surrounding the unimproved stops increased between the before and after periods by an average of 114 rides, annually (column B). Demand in the areas around the improved stops, however, decreased by an average of nine rides, annually (column A). This means that the average treatment effect on paratransit demand was 123 fewer rides per stop. Put another way, the growth in paratransit demand was $108 \%$ lower in the areas around the stops with improvements than around those without. This result was also statistically significant, but at the 0.1 level.

Table 4.3: Effect of Bus Stop Improvement on Changes in Stop-Level Bus Boardings and Paratransit Demand

\begin{tabular}{l|c|c|c|c}
\hline \multirow{2}{*}{ Outcomes } & $(\mathbf{A})$ & $\mathbf{( B )}$ & $\begin{array}{c}(\mathbf{C}) \\
=(\mathrm{A})-(\mathrm{B})\end{array}$ & $\begin{array}{c}\text { (D) } \\
=(\mathrm{C}) /(\mathrm{B})\end{array}$ \\
\cline { 2 - 5 } & $\begin{array}{c}\text { Mean of } \\
\text { Treatment } \\
\text { Group }\end{array}$ & $\begin{array}{c}\text { Mean of } \\
\text { Control } \\
\text { Group }\end{array}$ & $\begin{array}{c}\text { Average } \\
\text { Treatment } \\
\text { Effect (ATE) }\end{array}$ & $\begin{array}{c}\text { ATE/ } \\
\text { Control Ratio }\end{array}$ \\
\hline $\begin{array}{l}\text { Change in Bus Ridership } \\
\text { between 2013 and 2016 }\end{array}$ & 5,453 & 2,260 & $3,193^{* *}$ & 1.41 \\
\hline $\begin{array}{l}\text { Change in Paratransit Demand } \\
\text { between 2013 and 2016 }\end{array}$ & -9 & 114 & $-123^{*}$ & -1.08 \\
\hline **: $p<.05, *: p<.1$ (independent t-test results) & & &
\end{tabular}

These results were very encouraging. They were consistent with the findings from the initial phase of the project, but this time with statistical controls. Still, it would be a mistake to assert that improving bus stops leads to overall ridership increases on scheduled-service buses or to mode shifts from ADA paratransit to scheduled services. The increases we observed at the improved stops could have come from existing riders merely switching from unimproved stops to those with the new improvements. This is something suggested in research by Chu (2004). The close proximity of some of the improved and unimproved stops in our analysis (see Figure 4.7) supports such a hypothesis. Other limitations of this analysis are sourced in the team's use of a small sample size from a single county within a limited time frame. These factors, among others, inhibit generalizing on the results.

Still, the results were encouraging, especially those related to possible impacts on ADA paratransit usage. To get a greater degree of confidence on the possible demand impacts from bus stop improvements, the team needed to dig deeper.

\subsection{PHASE III: PROPENSITY SCORE WEIGHTING}

In the most recent phase of the project, the research team has sought to address some of the limitations, noted above, first by expanding the geographic reach of the analysis to include the entirety of the UTA service area-six counties covering more than 1,400 square miles and containing 6,347 bus stops. Between 2014 and 2017, UTA improved 128 of these stops. As before, these improvements included the following elements: an overhead shelter, a bench, an ADA-compliant concrete pad, and a garbage can. The 
team excluded 41 of these stops because of their location at a rail-transit stop, along seasonal ski-bus routes, or in a remote rural portion of the service area-all factors that could skew the analysis. This left 87 improved stops to serve as the "treatment group."

The team also eliminated stops with these attributes from possible inclusion in the control group, as well as stops that had been improved before 2014. This left a total of 3,707 unimproved stops that could serve as the control group. Figure 4.8 depicts the geographic locations of both groups of stops.

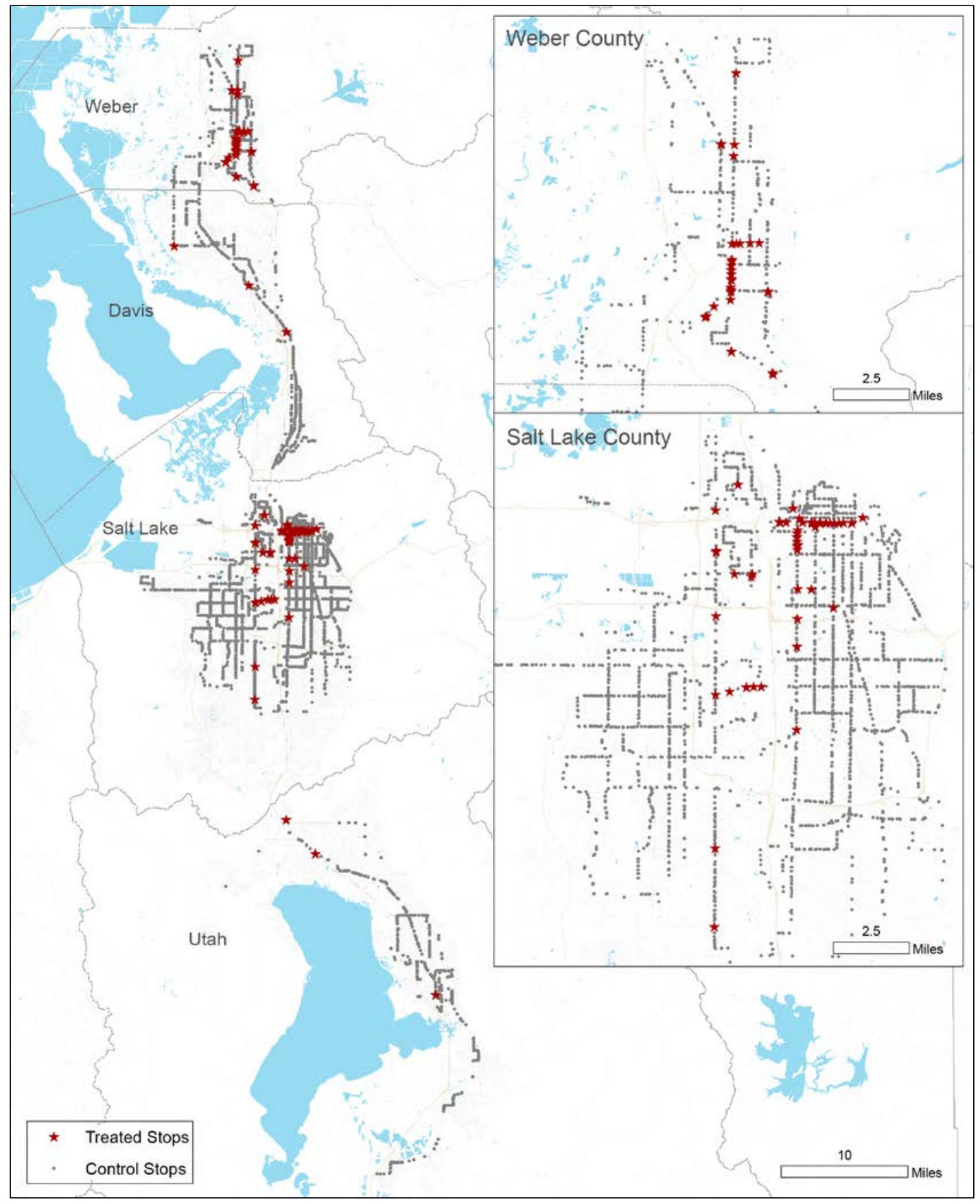

Figure 4.8..Location of treated and control stops for Phase III. 
To control for possible confounding influences in the analysis, the team relied on an approach similar to the one used in Phase II (i.e., looking to extant academic and professional literature to identify factors, other than stop improvements) that could explain changes in demand. The team used 26 such factors for this phase of the study, which are listed in Table 4.4.

Table 4.4. Description of Variables for Phase III

\begin{tabular}{l|l}
\hline Variables & Description \\
\hline White & $\%$ of Non-Hispanic white population \\
\hline Worker & $\%$ of total workers 16 years and over \\
\hline Commuter by car & $\%$ of workers who commute by car \\
\hline Working at home & $\%$ of workers who work at home \\
\hline Household & Total household \\
\hline Household size & Household size \\
\hline Household living alone & Household living alone \\
\hline Household with 18 & $\%$ of Households with one or more people under 18 years \\
\hline Household with 65 & $\%$ of Households with one or more people 65 years and over \\
\hline Students in college & Students enrolled in college, graduate or professional school \\
\hline Higher education & Higher educational attainment for the population 25+ years \\
\hline Median household income & Median household income \\
\hline Renter & $\%$ of renter occupied household \\
\hline Job & Total job \\
\hline Household with poverty level & $\%$ of household annual income below poverty level \\
\hline Public assistance household & Household with public assistance income \\
\hline No car & $\%$ of household with no vehicle available \\
\hline Disability & $\%$ of Population 18 years and over with a disability \\
\hline Entropy & Land use mix \\
\hline Activity Density & Population + employment / gross land area in square mile \\
\hline JobPop balance & Job-Population balance within a quarter mile buffer \\
\hline Intersection Density & Intersection density \\
\hline Transit stop Density & Transit stop density \\
\hline Employment w/i 10 min by car & $\%$ employment w/i 10 min by car in TAZ where a stop located \\
\hline Employment w/i 30 min by car & $\%$ employment w/i 30 min by car in TAZ where a stop located \\
\hline Employment w/i 30 min by & $\%$ employment w/l 30 min by transit in TAZ where a stop \\
transit & located \\
\hline & \\
\hline
\end{tabular}

As with the Phase II analysis, the team used data on stop-level boardings of scheduled service buses reported through UTA's use of automatic passenger counting sensors. This time, the team selected data from 2013 and 2018 for the before-and-after periods, using only those data associated with either the 87 treatment group or 3,707 control group stops. Also similar to Phase II, the team received geocoded pick-up locations for ADA paratransit service for 2013 and 2018, again, selecting only those data located within a quarter-mile network distance of the treatment and control group stops. 
UTA also provided the team with data on the deployment of onboard bus ramps and the use of a special tap-on pass called the Freedom Access Pass. Every bus in the current UTA scheduled-service flight is a low-floor vehicle that has a swing-out ramp that operators activate for riders who require assistance boarding the bus. As such, ramp deployment frequency is potentially indicative of boardings by individuals with mobilityrelated disabilities, though it is probably over-inclusive in that operators sometimes activate ramps for other riders (e.g., riders with strollers or rolling grocery baskets). Nevertheless, ramp deployment rates provide some evidence of use of scheduledservice buses by riders with disabilities, as was suggested in the research by Thatcher et al. (2013), noted above. A more direct measure, however, is possible by assessing use rates of the Freedom Access Pass (FAP). UTA issues FAPs to patrons who qualify for ADA paratransit service, allowing them to use the scheduled service for free. FAPs utilize electronic tap technology, making the collection of the data fairly simple. By measuring ramp deployments and FAP taps-along with scheduled-service boardings and ADA paratransit pick-ups-the team hoped to observe better possible shifts by riders with disabilities from ADA paratransit service to scheduled service.

For this analysis, the team elected to use propensity scores in a way different from the Phase II analysis. Instead of using scores for a matched pair analysis, we decided to use a propensity score weighting technique, a decision tree-based iterative machine learning method that is more suitable for the large set of covariates involved in our assessment (Mccaffrey, Rigeway \& Morral, 2004; Lee, Lessler \& Stuart, 2010; Olmos \& Govindasamy, 2015). The study team used R 3.6.1 to estimate propensity scores using pre-treatment covariates that affect both the treatment assignments and outcomes. For more detailed information on methods the team used for this analysis, see Appendix A.

The team first examined changes in boardings on scheduled-service buses, running the model both before and after weighting the propensity scores (Table 4.5). The analysis showed that before weighting, stop improvements were not significantly associated with boardings. After weighting, however, the model showed this association to be statistically significant and positive, suggesting that stop improvements were linked to increased boardings. 
Table 4.5: Bus Stop Improvements and Change in Bus and ADA Paratransit Ridership Using Propensity Score Weighting

\begin{tabular}{|c|c|c|c|c|c|c|c|c|c|c|c|c|}
\hline \multirow{4}{*}{$\begin{array}{l}\text { Variable } \\
\text { (Intercept) }\end{array}$} & \multicolumn{6}{|c|}{$\Delta$ Bus Ridership } & \multicolumn{6}{|c|}{$\Delta$ Paratransit Ridership } \\
\hline & \multicolumn{3}{|c|}{ Unweighted } & \multicolumn{3}{|c|}{ Weighted } & \multicolumn{3}{|c|}{ Unweighted } & \multicolumn{3}{|c|}{ Weighted } \\
\hline & \multicolumn{2}{|c|}{ Estimate } & \multirow{2}{*}{$\begin{array}{c}\begin{array}{c}\text { Std. } \\
\text { Error }\end{array} \\
2339.009\end{array}$} & \multicolumn{2}{|c|}{ Estimate } & \multirow{2}{*}{$\begin{array}{c}\begin{array}{c}\text { Std. } \\
\text { Error }\end{array} \\
3438.000\end{array}$} & \multicolumn{2}{|c|}{ Estimate } & \multirow{2}{*}{$\begin{array}{c}\begin{array}{c}\text { Std. } \\
\text { Error }\end{array} \\
237.2951\end{array}$} & \multicolumn{2}{|c|}{ Estimate } & \multirow{2}{*}{\begin{tabular}{|c|}
$\begin{array}{c}\text { Std. } \\
\text { Error }\end{array}$ \\
285.100
\end{tabular}} \\
\hline & 1378.554 & & & 13340.000 & 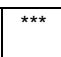 & & 1335.794 & $\bar{k}^{* * *}$ & & 1163.000 & 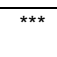 & \\
\hline $\begin{array}{l}\text { Bus Stop } \\
\text { Treatment }\end{array}$ & 487.745 & & 361.529 & 719.300 & $* \star \star$ & 187.300 & -17.642 & & 35.70515 & -28.450 & . & 15.030 \\
\hline White & -3.961 & & 6.631 & -6.751 & & 9.645 & -0.679 & & 0.672 & -2.349 & ** & 0.795 \\
\hline Worker & 20.580 & & 18.116 & 36.610 & & 26.570 & -8.448 & $* * *$ & 1.83684 & -11.290 & $* \star \star$ & 2.202 \\
\hline $\begin{array}{l}\text { Commute } \\
\text { by car }\end{array}$ & -53.374 & $* * *$ & 14.541 & -151.200 & 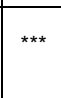 & 21.210 & -2.665 & . & 1.47376 & 0.474 & & 1.757 \\
\hline $\begin{array}{l}\text { Working at } \\
\text { home }\end{array}$ & -100.327 & ** & 32.300 & -470.600 & $* \star \star$ & 46.400 & -4.740 & & 3.27231 & -8.462 & * & 3.844 \\
\hline $\begin{array}{l}\text { Household } \\
\text { size }\end{array}$ & 407.173 & & 233.469 & 1302.000 & $* * \star$ & 360.000 & -32.491 & & 23.67261 & -0.441 & & 29.910 \\
\hline Household & 1.476 & & 0.864 & 5.323 & $* * \star$ & 1.247 & -0.179 & * & 0.08763 & -0.462 & 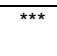 & 0.103 \\
\hline $\begin{array}{l}\text { Household } \\
\text { living alone }\end{array}$ & -0.909 & & 0.746 & -5.106 & $* \star \star$ & 1.027 & 0.089 & & 0.07563 & 0.331 & $* * *$ & 0.085 \\
\hline $\begin{array}{l}\text { Household } \\
\text { with } 18\end{array}$ & 16.669 & & 12.241 & -46.480 & ** & 18.000 & -5.075 & $* * *$ & 1.24083 & -6.504 & $* * *$ & 1.493 \\
\hline $\begin{array}{l}\text { Household } \\
\text { with } 65\end{array}$ & 15.067 & & 12.232 & 27.800 & . & 16.860 & -6.015 & $* * *$ & 1.23939 & -9.013 & $* * *$ & 1.385 \\
\hline $\begin{array}{l}\text { Students in } \\
\text { college }\end{array}$ & -0.292 & & 0.179 & -1.367 & $* * *$ & 0.267 & -0.025 & & 0.01815 & -0.003 & & 0.022 \\
\hline $\begin{array}{l}\text { Higher } \\
\text { education }\end{array}$ & -0.152 & & 0.258 & 0.019 & & 0.387 & 0.026 & & 0.02611 & 0.080 & * & 0.032 \\
\hline $\begin{array}{l}\text { Median } \\
\text { household } \\
\text { income }\end{array}$ & 14.014 & * & 6.160 & 35.290 & $* * *$ & 9.456 & -0.973 & & 0.62466 & 0.591 & & 0.779 \\
\hline Renter & 5.330 & & 6.565 & -54.430 & $* \star \star *$ & 9.200 & -0.697 & & 0.66705 & 5.906 & $* \star \star *$ & 0.763 \\
\hline Job & 0.433 & * & 0.210 & 1.258 & $* * \star$ & 0.305 & -0.049 & * & 0.02133 & -0.092 & $* * *$ & 0.025 \\
\hline $\begin{array}{l}\text { Household } \\
\text { below } \\
\text { poverty } \\
\text { level }\end{array}$ & -14.311 & & 15.068 & 39.900 & & 22.130 & -2.804 & & 1.5273 & -11.220 & $* * *$ & 1.830 \\
\hline
\end{tabular}




\begin{tabular}{|c|c|c|c|c|c|c|c|c|c|c|c|c|}
\hline \multirow{4}{*}{$\begin{array}{l}\text { Variable } \\
\text { Household } \\
\text { with public } \\
\text { assistance }\end{array}$} & \multicolumn{6}{|c|}{$\Delta$ Bus Ridership } & \multicolumn{6}{|c|}{$\Delta$ Paratransit Ridership } \\
\hline & \multicolumn{3}{|c|}{ Unweighted } & \multicolumn{3}{|c|}{ Weighted } & \multicolumn{3}{|c|}{ Unweighted } & \multicolumn{3}{|c|}{ Weighted } \\
\hline & \multicolumn{2}{|c|}{ Estimate } & $\begin{array}{l}\text { Std. } \\
\text { Error }\end{array}$ & \multicolumn{2}{|l|}{ Estimate } & $\begin{array}{l}\text { Std. } \\
\text { Error }\end{array}$ & \multicolumn{2}{|l|}{ Estimate } & $\begin{array}{l}\text { Std. } \\
\text { Error }\end{array}$ & \multicolumn{2}{|l|}{ Estimate } & $\begin{array}{l}\text { Std. } \\
\text { Error }\end{array}$ \\
\hline & \multicolumn{2}{|l|}{-1.564} & 2.693 & \multicolumn{2}{|l|}{1.644} & 3.951 & \multicolumn{2}{|l|}{0.460} & 0.273 & \multicolumn{2}{|l|}{-0.109} & 0.328 \\
\hline No car & 32.721 & & 19.622 & -30.340 & & 27.850 & -6.319 & ** & 1.99018 & -8.769 & $x^{* \star \star}$ & 2.291 \\
\hline Disability & -39.016 & & 29.273 & -176.300 & *** & 42.490 & -0.162 & & 2.9648 & 13.330 & $* \star \star$ & 3.499 \\
\hline Activity Den & -0.245 & & 0.161 & -0.691 & $* \star$ & 0.235 & 0.042 & * & 0.01631 & 0.075 & $* \star *$ & 0.019 \\
\hline $\begin{array}{l}\text { JobPop } \\
\text { Balance }\end{array}$ & 58.920 & & 298.800 & -1010.000 & * & 436.400 & -55.076 & . & 30.30502 & -92.760 & ** & 35.990 \\
\hline Entropy & -44.702 & & 341.714 & -1468.000 & ** & 486.800 & 35.585 & & 34.72626 & -30.550 & & 40.780 \\
\hline $\begin{array}{l}\text { Intersection } \\
\text { Density }\end{array}$ & 1.176 & & 1.830 & -4.891 & . & 2.832 & -0.201 & & 0.18564 & 0.175 & & 0.235 \\
\hline $\begin{array}{l}\text { Transit Stop } \\
\text { Density }\end{array}$ & 0.592 & & 7.366 & 23.090 & * & 9.814 & -1.871 & * & 0.74751 & -4.778 & $* \star \star$ & 0.813 \\
\hline $\begin{array}{l}\text { Employment } \\
\text { within } 10 \\
\text { min by car }\end{array}$ & 17.719 & & 16.444 & 0.321 & & 21.730 & -1.055 & & 1.66765 & -0.507 & & 1.800 \\
\hline $\begin{array}{l}\text { Employment } \\
\text { within } 30 \\
\text { min by car }\end{array}$ & -5.182 & & 3.773 & -19.890 & $* \star *$ & 5.470 & 0.715 & . & 0.38244 & -0.063 & & 0.454 \\
\hline $\begin{array}{l}\text { Employment } \\
\text { within } 30 \\
\text { min by } \\
\text { transit }\end{array}$ & 1.968 & & 12.415 & -5.809 & & 17.300 & 1.512 & & 1.25839 & 4.511 & $\star \star$ & 1.436 \\
\hline $\begin{array}{l}\text { Bus } \\
\text { ridership in } \\
2013\end{array}$ & 0.048 & $* \star *$ & 0.014 & 0.054 & $* \star *$ & 0.010 & -0.370 & $* * *$ & 0.01166 & -0.4531 & $* \star \star$ & 0.015 \\
\hline$F$ & & 6.65 & & & 7.33 & & & $39.4 \varepsilon$ & & & 9.16 & \\
\hline Prob $<F$ & & 0.00 & & & 0.001 & & & 0.00 & & & 0.001 & \\
\hline R-squared & & 0.04 & & & .217 & & & 0.230 & & & .268 & \\
\hline $\begin{array}{l}\text { Adjusted R- } \\
\text { squared }\end{array}$ & & 0.04 & & & .212 & & & 0.221 & & & .262 & \\
\hline
\end{tabular}

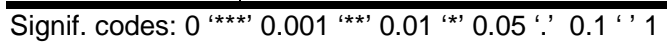

Similarly, the team's investigation of possible impacts on ADA paratransit demand showed that before applying the propensity score weights, there was no significant link 
between stop improvements and rates of ADA paratransit pick-ups. The weighted model, however, showed a connection between those variables that was both significant and negative, signaling that bus stop improvements may have been associated with reductions in ADA paratransit pick-up rates.

These two results-increased boardings on scheduled-service buses and reductions in ADA paratransit pick-ups-suggest that perhaps some ADA paratransit riders in areas near improved stops were switching to scheduled-bus service for at least some of their trips. To test this possibility, the team first assessed ramp deployment rates on scheduled-service buses, finding that increased ramp deployments were, in fact, significantly associated with bus stops that had been improved (Table 4.6). The team found similar results with respect to the usage of Freedom Access Passes: pass use increased significantly at stops that UTA had improved.

Table 4.6: Bus Stop Improvements and Changes in Ramp Deployment and Freedom Access Pass Use

\begin{tabular}{|c|c|c|c|c|c|c|}
\hline \multirow{3}{*}{$\begin{array}{l}\text { Variable } \\
\text { (Intercept) }\end{array}$} & \multicolumn{3}{|c|}{$\Delta$ Ramp Deployment } & \multicolumn{3}{|c|}{$\begin{array}{c}\Delta \text { Use of Freedom Access } \\
\text { Pass }\end{array}$} \\
\hline & \multicolumn{2}{|c|}{ Estimate } & \multirow{2}{*}{$\begin{array}{r}\text { Std. Error } \\
39.220\end{array}$} & \multicolumn{2}{|c|}{ Estimate } & \multirow{2}{*}{$\begin{array}{r}\text { Std. Error } \\
24.050\end{array}$} \\
\hline & 17.950 & & & 128.800 & $* * \star$ & \\
\hline Bus Stop Treatment & 16.260 & 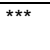 & 4.534 & 15.400 & *** & 2.712 \\
\hline White & 0.302 & & 0.209 & -0.401 & ** & 0.127 \\
\hline Household size & -7.295 & & 5.553 & -17.410 & $* \star \star$ & 3.388 \\
\hline Household & 0.042 & ** & 0.013 & -0.007 & & 0.008 \\
\hline Household living alone & -0.048 & *** & 0.013 & -0.021 & * & 0.008 \\
\hline Household with 65 & 0.449 & & 0.338 & -0.312 & & 0.204 \\
\hline Higher education & -0.031 & $x^{* \star \star}$ & 0.009 & -0.008 & & 0.006 \\
\hline Median household income & 0.208 & & 0.222 & 0.061 & & 0.136 \\
\hline Renter & -0.815 & 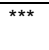 & 0.223 & 0.030 & & 0.136 \\
\hline Household below poverty & -0.870 & & 0.469 & -1.220 & *** & 0.286 \\
\hline Public assistance household & 0.229 & * & 0.096 & 0.018 & & 0.058 \\
\hline No car & 3.495 & 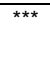 & 0.648 & 2.150 & $* \star \star$ & 0.396 \\
\hline Disability & -4.575 & *** & 1.034 & -2.831 & $* * \star$ & 0.626 \\
\hline Activity Density & 0.006 & *** & 0.001 & 0.004 & $* \star \star$ & 0.001 \\
\hline JobPop Balance & 10.290 & & 10.530 & 15.940 & * & 6.436 \\
\hline Entropy & 53.350 & *** & 11.730 & -9.503 & & 7.149 \\
\hline
\end{tabular}




\begin{tabular}{|c|c|c|c|c|c|c|}
\hline \multirow{3}{*}{$\begin{array}{l}\text { Variable } \\
\text { Intersection Density }\end{array}$} & \multicolumn{3}{|c|}{$\Delta$ Ramp Deployment } & \multicolumn{3}{|c|}{$\begin{array}{c}\Delta \text { Use of Freedom Access } \\
\text { Pass }\end{array}$} \\
\hline & \multicolumn{2}{|c|}{ Estimate } & Std. Error & \multicolumn{2}{|c|}{ Estimate } & Std. Error \\
\hline & -0.108 & & 0.066 & -0.036 & & 0.040 \\
\hline Transit Stop Density & 0.813 & 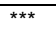 & 0.235 & 0.367 & * & 0.143 \\
\hline Employment w/i 10 min car & 2.118 & *k* & 0.535 & -0.651 & * & 0.327 \\
\hline Employment w/i 30 min car & -0.511 & *** & 0.137 & -0.383 & 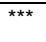 & 0.083 \\
\hline Employment w/i 30 min transit & -0.420 & & 0.428 & 0.794 & ** & 0.260 \\
\hline $\begin{array}{l}\text { Ramp Deployment / Freedom } \\
\text { Access Card Tap-on in } 2013\end{array}$ & 2.182 & $* * *$ & 0.042 & 0.072 & *** & 0.016 \\
\hline $\mathrm{F}$ & \multicolumn{3}{|c|}{270.20} & \multicolumn{3}{|c|}{34.54} \\
\hline Prob $<F$ & \multicolumn{3}{|c|}{$<0.001$} & \multicolumn{3}{|c|}{$<0.001$} \\
\hline R-squared & \multicolumn{3}{|c|}{0.612} & \multicolumn{3}{|c|}{0.168} \\
\hline Adjusted R-squared & \multicolumn{3}{|c|}{0.610} & \multicolumn{3}{|c|}{0.163} \\
\hline
\end{tabular}

To quantify the relative impacts of stop improvements, the team first calculated an Observed Total Effect using a method reported by Deng and Yan (2019) (Table 4.7). Observed Total Effect is the mean difference of change in the four outcome variablesbus boardings, ADA paratransit use, ramp deployment, and Freedom Access Pass use-between treatment and control groups measured before weighting. Average Bus Stop Treatment Effect, on the other hand, is the mean difference of change in those same four variables measured after weighting, effectively providing a measure of the magnitude of change that is attributable to stop improvement. The analysis shows that for bus boardings, $51 \%$ of the total increase was associated with stop improvements. For ADA paratransit demand, the degree of treatment effect was much larger at $134 \%$, suggesting that stop improvements had a substantial influence in reducing demand even while other factors may have been increasing it. While only $11 \%$ of the total change in ramp deployment was attributable to stop improvements, $41 \%$ of the increased use of Freedom Access Passes was tied to the improvements. 
Table 4.7: Effects of Bus Stop Improvements

\begin{tabular}{l|r|r|r}
\hline & $\begin{array}{c}\text { Observed Total } \\
\text { Effect } \\
\text { (A) }\end{array}$ & $\begin{array}{c}\text { Average Bus Stop } \\
\text { Treatment Effect } \\
\text { (ATE) }\end{array}$ & $\begin{array}{c}\text { Proportion of } \\
\text { Treatment Effect } \\
\text { in Total Effect } \\
\text { (ATE)/(A) }\end{array}$ \\
\hline$\Delta$ Bus Ridership & 1406.44 & 719.30 & $51 \%$ \\
\hline$\Delta$ Paratransit Ridership & -21.28 & -28.45 & $134 \%$ \\
\hline$\Delta$ Ramp Deployment & 142.64 & 16.26 & $41 \%$ \\
\hline$\Delta$ Freedom Access Pass Use & 37.57 & 15.40 & $11 \%$ \\
\hline
\end{tabular}

These results confirmed the team's findings from earlier phases of the project but provided increased confidence that associations between stop improvements and increased scheduled-service boardings and decreased ADA paratransit use represent actual outcomes in the Salt Lake region during the time periods in question. In terms of magnitude, the change in ADA paratransit demand associated with stop improvements is much smaller than the change noted for scheduled-service boardings, suggesting that the effects of stop improvements go beyond just facilitating mode shifts from ADA paratransit to scheduled service. In other words, the data suggest that improved stops are appealing to riders of all abilities, not just those who qualify for ADA paratransit. 


\subsection{QUALITATIVE DATA}

The analysis so far has relied on assessments of quantitative information, aggregated to fairly large geographic areas. To better understand the importance of making bus stop improvements, the team sought to employ qualitative research techniques, specifically through structured interviews and focus groups. These types of qualitative data can provide insight to addressing some of the questions of how and why UTA riders appear to be responding to the bus stop improvements, as suggested by the quantitative analyses. The hope is that the qualitative information can provide a peek inside the story implied by the quantitative data (Rogers \& Goodrick, 2010).

During a three-month period of December 2019 through February 2020, the team conducted qualitative investigations with three consistencies: UTA riders who have identified themselves as having disabilities that impact their mobility, UTA personnel involved in providing service to riders with disabilities, and advocates for such riders. Though these three groups are distinct, their composition is somewhat overlapping, particularly with respect to some of the riders who also played advocacy roles.

The investigations included two focus groups, one comprised of riders with disabilities who were recruited for the focus group by UTA, the other comprised of members of UTA Committee on Accessible Transit (CAT), an advisory committee empaneled by the agency to give input on service and facilities issues. In addition, the team interviewed six individuals, including one rider (who was recruited for a focus group but could not make the meeting), the UTA Civil Rights Compliance Officer, two UTA staff involved in ADA evaluations and travel training, and two staff members of a local nonprofit organization active on disability issues.

The team's qualitative work is still ongoing. Over the next nine months we expect to interview national-level planners, agency personnel, and advocates to gain further insights. Hence, the analysis of our data gathered to date is preliminary. Here, however, are some of the themes that are emerging from the data.

\subsection{SHELTERS}

Several of the participants indicated support for the construction of more shelters at stops, especially for protection against extreme weather. As one stated: "I would like to see more of the bus stops ... during the summer have canopies over them so the sun's not beating down on it. You know because here in Utah, it can get very, very hot. And I know some [of the stops] do. But even when it snows ... it would be nice just to keep the snow off of it." This comment underscores the quantitative observation made by Miao et al. (2016) about the apparent effect of stop shelters mitigating the normal downward trend in bus ridership during extreme weather.

Another supportive comment endorsed UTA's recent practice of situating the route sign pole in a consistent location at the stop. "[I]n the old days, ... bus stops were so different [from each other]. Sometimes [the pole was] in the ground, sometimes . . . with 
a shelter, sometimes ... on the other side of the sidewalk, away from the curb, depending on trees. [I]f I was going out and I had to just try and find a bus stop, that was incredibly stressful. These new standardized bus stops really decrease my stress level."

"My perfectly designed bus stop would be a bus shelter. It wouldn't have to be as big or elaborate as a lot of these that we have. But it would be a bus shelter with a bench. It would have on that shelter somewhere a push button or a sign or something in tactile numbers that would state what number bus stop you are at. Because they have a system . . . where you can call and if you know what bus stop you are at, you can . . . find out when the next bus is supposed to be there. I suppose that system works wonderfully [for sighted riders], but I can never know because . . . whenever I find a bus stop, there is no numbered sign or anything to tell me which bus [stop] it is."

Of course, making improvements to a nearby bus stop is unlikely to affect rider behaviors if riders are not aware of the improvements. A number of participants in our sessions lived within close proximity to one of the improved stops in our study, but did not know that the improvements had been constructed until they received the letter recruiting them for participation in our study.

A number of participants-riders with disabilities and advocates, alike-identified the lack of other features in the right-of-way that frequently impeded use of scheduled service buses, including the lack of sidewalks and curb cuts, particularly in suburban areas. "Where I live . . . there's no sidewalks where the bus stops are. So I often think, well, somebody gets off and needs to use a cane to be able to get themselves to the business or whatever. You're on grass. You're on nothing. If you use a wheelchair, how are you going to get yourself to whatever?" In places with sidewalks, many participants noted concern about inconsistent snow removal in winter months effectively barring access to bus stops. As one of the advocates reflected: "[While] I do think there are problems with the actual stops themselves, . . . their accessibility and whether a person can actually access where the bus is supposed to pick them up" is an even bigger problem. UTA takes account of these types of barriers in making eligibility determinations for ADA paratransit services in an assessment called a "home-stop analysis."

\subsection{OTHER ISSUES}

Current bus stop design practices present challenges for riders with disabilities beyond just the basic features that were the focus of our quantitative analyses (i.e., shelters, benches, concrete pads). A recurring issue that was raised by a number of participants in the focus groups and interviews is knowing where to physically situate oneself while waiting for the bus. This issue was particularly voiced by riders with vision impairments. Without a consistent protocol for specifying precisely where a bus "docks" in relation to the other features of a bus stop(e.g., the pole or the shelter)it is challenging for riders to know if they are in the correct spot for successfully boarding the bus. The worry expressed by these participants, born of multiple frustrating experiences one suspects, is waiting in a location that is not precisely where the bus pulls up, the bus arrives, 
opens its door, and then leaves before the rider has a chance to board. This worry, in fact, undercuts the utility of shelters, at least with some riders. If one is worried that the bus operator might not see the rider waiting in the shelter, the rider is unlikely to wait inside the shelter.

Another overarching concern for riders with disabilities is the cost of transit services, particularly for ADA paratransit. The current user-cost for using ADA paratransit is $\$ 4.00$ per one-way ride. Though only a fraction of the overall per trip cost for paratransit-UTA estimates the actual cost per ride is more than $\$ 59.00$ (UTA, 2020)-the user-paid fares for paratransit rides is a significant burden for a number of the riders involved in our focus groups and interviews. A related issue is the limit in geographic coverage of allowed pick-up services for ADA paratransit. As allowed by federal regulations, UTA limits paratransit service to those areas that are within three-quarters of a mile of scheduled-service routes. As one rider noted, this "limits where people can live in the community. It limits where they can recreate. That limits a lot of their life."

Auditory signals and stop announcements are another area of concern, again primarily for riders with impaired eyesight. Riders in our focus groups and interviews listed a number of points at which better auditory signals are needed, including exterior announcements as a bus pulls up identifying the bus's route number and name, and interior announcements identifying upcoming stops. At least one rider also highlighted the need for a user-activated announcement system at stops that would alert riders of the estimated time of arrival of the next bus. This "next bus" announcement system could also have a visual/text component that would assist riders with hearing impairments.

As noted above, the research team is still working to collect qualitative data, a task made more difficult by the COVID-19 pandemic. Because of these challenges, the team will be focusing its work on conducting structured interviews with planners working for Utah municipalities with agency staff at the Utah Department of Transportation and the U.S. Department of Transportation. It is hoped that this additional data will facilitate more in-depth analysis that can shed further light on how the features of bus stops can operate to increase riders' accessibility to opportunities in their communities. 


\subsection{CONCLUSION}

This report on the physical features of bus stops has demonstrated how important those features can be to riders, particularly those with mobility limitations. For this reason, the writers of this report have resisted the common practice of referring to such features as amenities. According to standard dictionary definitions of the term, amenity connotes items that are secondary, non-essential, even peripheral-like having a swimming pool at a roadside motel. For those who experience life with a mobility-related disability, however, the features of a bus stop can impact their ability to access food, health care, and basic economic, social, and educational opportunities. The ability of transit to provide access to these life functions is only as strong as the weakest link in the chain of circumstances between a rider's trip origin and destination. The failure of a bus stop to facilitate access to the transit system, hence, can bar a rider from accessing these fundamental functions. Seen in this light, bus stop features are not amenities but critical elements of infrastructure and should be treated as central to a transit system's function as more traditional elements. Given language's key role in defining and establishing intellectual concepts in general (Nuyts \& Pederson, 1997) and with respect to disability studies in particular (Linton, 2006; Krebs, 2019), the research team elected to consciously avoid amenities in favor of the more neutral term features.

The team's goal for this project was to assess whether improvements in the features included in bus stops can be linked to changes in the use of scheduled-service buses and the demand for ADA paratransit, at least in the Salt Lake City region during the time periods studied. Throughout the project's three phases, the team succeeded in building a case for affirmative responses to both of these issues. At this juncture, we can say with some confidence that improving the features of bus stops can lead to increased boardings at those stops and to reduced use of ADA paratransit by some users of those services.

The limitations of the project's findings, of course, are important to acknowledge. The data used for all three of the project's phases are from a single metropolitan region. Whatever the team could observe in Salt Lake City may not hold true in other locations. Miao et al.'s (2016) observations illustrate the truth of this assertion, showing that Salt Lake City bus riders reacted differently to the presence of shelters on bad weather days than riders in Chicago. Another limitation for the project surrounds our implicit assumption that the variables used to control for possible confounding influences in the analyses of overall boardings on scheduled-service buses are appropriate for our analyses of demand by persons with disabilities. The demographic and land use variables that influence general ridership on scheduled-service transit, which formed the basis of our analysis, are well-researched and validated. The factors that influence transit use by those with disabilities, however, is less well-researched. This project provides some insight into those questions, but much more investigation is needed.

Another implicit limitation of our work is that the features we investigated are just a subset of things that are important and often necessary to overcome as barriers to accessibility. As our focus group and interview data show, the impediments that stand in 
the way of many riders' ability to access transit include a general lack of tactile and verbal information at stops and onboard buses, missing sidewalks and crosswalks in the areas surrounding the stops, snow removal from said sidewalks and crosswalks, and operational consistency on how buses "dock" at stops.

Nevertheless, the findings from this project underscore the importance of bus stops as the point of first contact between a transit agency and its customers, and how stop design demonstrates the agency's attitude toward existing and potential riders. The data analyzed by our team show that how stops are designed and constructed matter to riders and that these decisions can make a difference in facilitating increased use of bus networks. Most importantly, the data bolster arguments for increased efforts to improve bus stops as a way to increase accessibility to transit for those with mobility-related disabilities. The qualitative information also provides a platform to expand future research efforts into areas that investigate additional barriers beyond the narrowly defined features our team explored. 


\section{REFERENCES}

M. Buchanan \& K. Hovenkotter. From Sorry to Superb: Everything You Need to Know about Great Bus Stops. New York: Transit Center. 2018.

S. Brown, F. Cable, K. Chalmers, C. Clark, L. Jones, G. Kueber, E. Landfried, C. Liles, N. Lindquist, X. Pan, R.A. Ray, Z. Shahan, C. Teague \& E. Yasukochi. "Understanding How the Built Environment Around TTA Stops Affects Ridership." PLAN 823 Fall Workshop. University of North Carolina, Chapel Hill. 2006.

X.J. Cao \& J. Schoner. The Influence of Light Rail Transit on Transit Use: An Exploration of Station Area Residents along the Hiawatha Line in Minneapolis. Transportation Research Part A: Policy and Practice, 59: 134-143. https://doi.org/10.1016/j.tra.2013.11.001. 2014.

X. Cao, Z. Xu \& Y. Fan. Exploring the Connections among Residential Location, SelfSelection, and Driving: Propensity Score Matching with Multiple Treatments.

Transportation Research Part A: Policy and Practice, 44: 797-805. https://doi.org/10.1016/j.tra.2010.07.010. 2010.

X. Chu. Ridership Models at the Stop Level Final Report. National Center for Transit Research. 2004.

R.B. D'Agostino. Propensity Score Methods for Bias Reduction in the Comparison of a Treatment to a Non-Randomized Control Group. Statistics in Medicine 17: 2265-2281. 1998.

R.H. Dehejia \& S. Wahba. Propensity Score-Matching Methods for Nonexperimental Causal Studies. Review of Economics and Statistics 84: 151-161. https://doi.org/10.1162/003465302317331982. 2002.

Y. Deng, Y., and Y. Yan. Propensity Score Weighting with Generalized Boosted Models to Explore the Effects of the Built Environment and Residential Self-Selection on Travel Behavior. Transportation Research Record, Vol. 2673, No. 4, 2019, pp. 373-383. https://doi.org/10.1177/0361198119837153.

J. Dill, M. Schlossberg, L. Ma \& C. Meyer. "Predicting Transit Ridership at the Stop Level: The Role of Service and Urban Form." Transportation Research Board 92nd Annual Meeting. Washington, D.C. https://doi.org/10.1016/.j.sbspro.2013.11.183. 2013.

T. Duncan \& S. Moriarty. Commentary on Relationship-Based Marketing Communication. Australian Marketing Journal 7(1): 118-120. 1999. 
T.R. Duncan. "A Macro Model of Integrated Marketing Communication." American Academy of Advertising Conference, Norfolk, VA. March 23-24, 1995.

R. Ewing. Research You Can Use: Assessing BIDs Using Propensity Score Marching. Planning, 81(1): 53-54. 2015.

R. Ewing \& R. Cervero. Travel and the Built Environment: A Meta-Analysis. Journal of the American Planning Association, 76(3): 265-294. 2010.

Y. Fan, A. Guthrie \& D. Levinson. Waiting Time Perceptions at Transit Stops and Stations: Effects of Basic Amenities, Gender, and Security. Transportation Research Part A: Policy and Practice, 88: 251-264. 2016.

Z. Guo, N. Wilson \& A. Rahbee. Impact of Weather on Transit Ridership in Chicago, Illinois. Transportation Research Record, 2034: 3-10. https://doi.org/10.3141/2034-01. 2007.

S. Higashide \& Z. Accuardi. Who's On Board 2016: What Today's Riders Teach Us About Transit That Works. New York: TransitCenter. 2016.

S. Jensen, A. Adkins, K. Bartholomew \& J. Kim. "Review of Bus Stop Amenity Guidelines." Transportation Research Board Annual Meeting, Washington, DC. 2020.

J. Kim, K. Bartholomew \& R. Ewing. Another One Rides the Bus? The Connections between Bus Stop Amenities, Bus Ridership, and ADA Paratransit Demand.

Transportation Research Part A: Policy and Practice, 135: 280-288. 2020.

E. Krebs. Baccalaureates or Burdens? Complicating "Reasonable Accommodations" for American College Students with Disabilities. Disabilities Studies Quarterly, 39(3). DOI: http://dx.doi.org/10.18061/dsq.v39i3.6557. 2019.

D.M. Krugman \& J.L. Hayes. Brand Concepts and Advertising, in S. Rodgers \& E. Thorson (eds.) Advertising Theory, 491-505. New York: Routledge. 2012.

G. Kuntzman. It's Over! Vancouver Has 'Sorriest Bus Stop'. StreetsBlog, https://usa.streetsblog.org/2018/09/14/its-over-vancouver-has-the-sorriest-bus-stop-instreetsblogs-annual-contest/. 2018.

B.K. Lee, J. Lessler \& E.A. Stuart. Improving Propensity Score Weighting Using Machine Learning. Statistics in Medicine, 29(3): 337-346. https://doi.org/10.1002/sim.3782. 2010.

W. Leite. Practical Propensity Score Methods Using R. Sage: Thousand Oaks, CA. 2017. 
S. Linton. Reassigning Meaning. In L.J. Davis (ed.), The Disability Studies Reader, 933. Psychology Press. 2006.

D.F. Mccaffrey, G. Ridgeway \& A.R. Morral. Propensity Score Estimation with Boosted Regression for Evaluating Causal Effects in Observational Studies. Psychological Methods, 9(4): 403-425. https://doi.org/https://doi.org/10.1037/1082-989X.9.4.403. 2004.

M. Meng, A. Rau \& H. Mahardhika. Public Transport Travel Time Perception: Effects of Socioeconomic Characteristics, Trip Characteristics and Facility Usage. Transportation Research Part A: Policy and Practice, 114: 24-37. https://doi.org/10.1016/j.tra.2018.01.015. 2018.

Q. Miao, E. Welch \& P.S. Sriraj. Decision Analysis to Address Extreme Weather: Extreme Weather Effects on Ridership and Modeling the Decision to Invest in Canopy Coverage. Center for Urban Transportation Research: Tampa, FL. 2016.

S. Moriarty \& D. Schultz. Four Theories of How IMC Works, in S. Rodgers \& E. Thorson (eds.), Advertising Theory, 491-505. New York: Routledge. 2012.

J. Nuyts \& E. Pederson. Language and Conceptualization. Cambridge University Press: Cambridge, UK. 1997.

A. Olmos \& P. Govindasamy. A Practical Guide for Using Propensity Score Weighting in R. Practical Assessment. Research and Evaluation, 20(13): 1-8. 2015.

K. Park, R. Ewing, B.C. Scheer \& S.S. Ara Khan. Travel Behavior in TODs vs. NonTODs: Using Cluster Analysis and Propensity Score Matching. Transportation Research Record, 2672(6): 31-39. https://doi.org/10.1177/0361198118774159. 2018.

P. Rogers \& D. Goodrick. Qualitative Data Analysis. In J. Wholey, H. Hatry \& K. Newcomer (eds.), Handbook of Practical Program Evaluation, 429-453. Jossey-Bass: San Francisco. 2010.

P.R. Rosenbaum \& D.B. Rubin. The Central Role of the Propensity Score in Observational Studies for Causal Effects. Biometrika, 70: 41-55. https://doi.org/10.2307/2335942. 1983.

SBW. "Seoul District Bus Stops Keep Riders Warm." The Korea Bizwire: Seoul. http://koreabizwire.com/seoul-district-bus-stops-keep-riders-warm/110895. 2018.

V. Stover \& E. McCormack. The Impact of Weather on Bus Ridership in Pierce County, Washington. Journal of Public Transportation, 15: 95-110. https://doi.org/10.5038/23750901.15.1.6. 2012. 
D. Sucher. City Comforts: How to Build an Urban Village. City Comforts: Seattle, WA. 2003.

S.A. Sutton. Are BIDs Good for Business? The Impact of BIDs on Neighborhood Retailers in New York City. Journal of Planning Education and Research, 34(3): 309324. https://doi.org/10.1177/0739456X14539015. 2014.

M.R. Talbott. "Bus Stop Amenities and their Relationship with Ridership: A Transportation Equity Approach." Master's Thesis. The University of North Carolina at Greensboro. 2011.

E. Talen. Housing Demolition During Urban Renewal. City and Community, 13(3): 233253. https://doi.org/10.1111/cico.12070. 2014.

R. Thatcher, C. Ferris, D. Chia, J. Purdy, B. Ellis, B. Hamby, J. Quan \& M. Golden. Strategy Guide to Enable and Promote the Use of Fixed-Route Transit by People with Disabilities. TCRP Report, No. 163. Federal Transit Administration: Washington, D.C. 2013.

Utah Transit Authority. Comprehensive Annual Financial Report for Fiscal Years Ended December 31, 2019 and 2018. UTA: Salt Lake City, UT. https://www.rideuta.com/Imedia/Files/About-UTA/Reports/2020/2020 CAFR-Master Final.ashx?la=en. 2020.

J. Walker. Human Transit: How Clearer Thinking About Public Transit Can Enrich Our Communities and Our Lives. Island Press: Washington, DC. 2012.

W. Wu, A. Gan, F. Cevallos \& L.D. Shen. Selecting Bus Stops for Accessibility Improvements for Riders with Physical Disabilities. Journal of Public Transportation, 14(2): 7. 2011.

A. Yoo. "EyeStop: A Futuristic Bus Stop is Here." My Modern Met. https://mymodernmet.com/eyestop-a-futuristic-bus-stop/. 2009.

A. Zandiatashbar, S. Hamidi, N. Foster \& K. Park. The Missing Link between Place and Productivity? The Impact of Transit-Oriented Development on the Knowledge and Creative Economy. Journal of Planning Education and Research, 39(4): 429-441. https://doi.org/10.1177/0739456X19826271. 2019. 


\section{APPENDIX A}

STEP-WISE ANALYTICAL METHODOLOGY FOR PHASE III ANALYSIS (AKA "THE COOKBOOK") 


\subsection{RESEARCH FRAME AND STOP-LEVEL DATA}

\subsection{UTA RESEARCH FRAME}

1. Before Period: 2013 (Jan-Dec)

2. Bus Stop Improvements: $2014-2017$

3. After Period: 2018 (Jan-Dec)

\subsection{UTA BUS STOP DATA}

UTA Service Area 2013(Dec) Bus Stop $(\mathrm{N}=6,329)$ - UTA data (GIS) 2018(Sep) Bus Stop ( $N=6,300)$ - AGRC data (GIS)

\subsection{SELECTING IMPROVED STOPS}

1. Select the improved stops that meet the criteria $(\mathrm{N}=155)$

- Overhead protection (e.g. shelter)

- ADA concrete pad

- Seating (e.g. bench)

$\rightarrow$ 2014-2017 All Improved Stops ( $=155)$ - UTA data

2. Exclude stops below $(\mathrm{N}=95)$

- Already had a shelter before $2014(\mathrm{~N}=11)$

: Check with Google Street View with the nearest year before 2014 for the existence of shelter in before-period

- Installed between 2014-2017, but currently removed for some reasons (e.g., new constructions) $(\mathrm{N}=2)$

- Bus stop at TRAX(Light rail) \& Frontrunner(Commuter rail) Station ( $\mathrm{N}=14)$

- UTA Park \& Ride Stop ( $N=1)$

- Newly added stop since 2014 ( $\mathrm{N}=14)$

o $\quad 25^{\text {TH }}$ ST @ 1176 E: No GIS Information in 2013, but the stop existed in 2011 google street view and the stop improved between 2014-2017.

- One stop location (2013) moved into two stop locations (2018) $(\mathrm{N}=2)$

- Stops not located in Weber, Davis, Salt Lake, and Utah County ( $N=16)$

$\rightarrow$ Selected Improved Stops (N=95)

3. Join the list of improved stops to 2018 bus stops

4. Match the Improved stops in 2018 with bus stops in 2013.

5. Manually find out the moved stops while stop improvements and input the information manually. 
6. Identify Corridor Improvements - create a binary variable \& text variable for corridor descriptions.

7. Add 'YEAR' variable and find the year of the improvement for each stop.

*After checking with other data, more stops can be excluded.

\subsection{SELECTING UNIMPROVED STOPS}

1. Open both '2013_BusStops' and '2018_BusStops' shapefile in ArcGIS

2. Join '2018_BusStops' to '2013_BusStops' based on StopID (or equivalent)

3. Export only the matched stops in 2013_BusStops

4. Exclude the stops selected as Improved Stops before editing with criteria (by checking StopID) and remove those.

5. Exclude stops that has a shelter

6. Exclude stops not located in Weber, Davis, Salt Lake, and Utah County

7. Exclude stops at TRAX(Light Rail) \& Frontrunner(Commuter rail) station $\rightarrow 2013$ Matched Bus Stops $(\mathrm{N}=4,860)$

*After checking with other data, more stops can be excluded.

\subsection{COMBINING THE STOPS}

1. Merge both improved and unimproved stops and create 'AllStop_Final'.

2. Create a $1 / 2$-mile buffer around the stops. 


\subsection{DEMOGRAPHIC DATA}

\subsection{PREPARING DATA}

1. Download selected lists of tables and block group shapefile from NHGIS (see Table 1)

2. Open in Excel, remove empty rows and irrelevant rows, select and rename the variables based on Table 1

3. Insert new rows and calculate the value based on Table 1

4. Open dbf file (UT_blck_grp_2015.dbf) in excel. Select only 'GEOID' and 'GISJOIN' and save as a new file.

5. In demographic file, add a row 'GEOID'

6. With vlookup function in excel put the right 'GEOID' from the new file from dbf.

7. Download WAC from US Census LODES (https://lehd.ces.census.gov/data/\#lodes) with selecting 'Version: LODES7' and 'State: (Utah)'

8. Because LODES is based on Census block data, we need to combine block data into census block group level in order to match those with demographic data.

a. 'GEOID' of Census block group has 12 numbers and Census block has 15 numbers, so we only need the left 12 numbers from block data. Use left function in excel to extract GEOID of block group.

b. Select all and insert pivot table in new spreadsheet.

c. Select only the calculated 'GEOID' and 'TOTJOB'

d. Copy the cells, except the column name and grand total rows, into a new sheet.

e. Rename the column names as before.

f. With vlookup function in excel put TOTJOB in demographic file.

9. Create 'TOTHHINC' with 'MEDHHINC' for GIS calculation (see Table 1).

10. Only select the columns for GIS selection and save as a csv file.

\subsection{CALCULATING DEMOGRAPHIC DATA}

1. "Model1_Demo_Layer" Toolbox

a. In ArcGIS, add the demographic csv file.

b. Join the table to block group shape file and export as a new file, "Blkgrp_Demo.shp".

c. Add a field 'Area_Acre' with double.

d. Calculate geometry with Acres US.

e. Right-click on "Model1_Demo_Layer" and open edit. 
f. Double-click on the first left 'Blk_Demo_Layer'.

g. Select the "Blkgrp_Demo.shp" for 'Blk_Demo_Layer'

h. [Add Fields] The model will automatically add empty fields for future calculation.

i. Double-click on the rightest circle, 'Blk_Demo.shp'.

j. Set the location of the saved file, "Blk_Demo.shp".

k. Run the model.

2. "Model2_Demo_Calculation" Toolbox

a. Right-click on "Model2_Demo_Calculation" and open edit.

b. Double-click on the top-left 'Blk_Demo'.

c. Select the "Blk_Demo" layer.

d. Double-click on the bottom-left 'Stop_Buffer'.

e. Select the shapefile of the $1 / 2$-mile buffer around all stops.

f. [Select By Location] The model will select the block groups that intersect with $1 / 2$-mile buffers around stops.

g. [Intersect] The model will intersect block groups with with $1 / 2$-mile buffer around stops.

h. [Add Geometry Atrributes] The model will add a field [POLY_AREA] to calculate 'Area' with 'Acres' unit.

i. [Add Fields] The model will add a field 'Per_Area'.

j. [Calculate Fields] The model will calculate the value as [POLY_AREA]/[Area_Acre]

k. [Calculate Fields] The model will calculate all new demographic variables as [demographic field]*[Per_Area]

I. Right-click on 'Dissolve' and set the location.

$\mathrm{m}$. [Dissolve] The model will dissolve the file.

- Dissolve Field: ORIG_FID

- Statistics Fields: All new demographic field

- Statistic Type: SUM

n. Run the model.

*The greyed parts will be automatically calculated in the model. There is no need to change any setting for those parts.

*We have had encountered technical problems to deal with all stops at once. Thus, we divided the buffers into several files with approx. 500 rows and run the model one by one. Later, we merged all files into one. 


\subsection{PREPARING LAND USE DATA}

1. We used parcel-level land use data with land use information

2. It is required to re-categorize the land use information into four categories: Residential, Commercial, Public, and Other.

3. Create 'LU' field and record the contents with RES, COM, PUB, and OTH.

\subsection{CALCULATING LAND USE DATA}

1. "Model3_LandUse" Toolbox
a. Right-click on "Model3_LandUse" and open edit.
b. Double-click on the top-left 'Landuse_Parcel' and select the land use parcel layer.
c. Double-click on the bottom-left 'Stop_Buffer'.
d. Select the shapefile of the $1 / 2$-mile buffer around all stops.
e. [Select By Location] The model will select the parcels that intersect with $1 / 2$-mile buffers around stops.
f. [Intersect] The model will intersect parcels with with $1 / 2$-mile buffer around stops.

g. [Add Geometry Atrributes] The model will add a field [POLY_AREA] to calculate 'Area' with 'Acres' unit.

h. [Add Fields] The model will add a field 'RES', 'COM', 'PUB' with float.

i. [Calculate Fields] The model will calculate the value as below.

$$
\begin{aligned}
& \text { if }[L U]=" R E S " \text { Then } \\
& \text { Value }=\left[P O L Y \_A R E A\right] \\
& \text { else } \\
& \text { Value }=0 \\
& \text { end if }
\end{aligned}
$$

j. Right-click on 'Dissolve' and set the location.

k. [Dissolve] The model will dissolve the file.

- Dissolve Field: ORIG_FID

- Statistics Fields: RES, COM, PUB

- Statistic Type: SUM

I. Run the model.

*We have had encountered technical problems to deal with all parcels at once. Thus, we divided the buffers into several files with approx. 500 rows and run the model one by one. Later, we merged all files into one.

2. Open the dissolved file and add field, 'Sum_Area'.

3. Calculate field as [SUM_RES] + [SUM_COM] + [SUM_PUB] 
4. Add fields, 'Per_RES', 'Per_COM', and 'Per_PUB'

5. Calculate each field as [SUM_(RES)] I [Sum_Area]

6. Add field, 'Entropy'

7. Calculate the field as
a. If [SUM_COM] $>0 \&$ [SUM_PUB] $>0 \&$ [SUM_RES] $>0$
val $=(-1)^{\star}\left(\left[\right.\right.$ Per_COM] ${ }^{*}$ Log $\left([\right.$ Per_COM] $)+[\text { Per_PUB }]^{\star}$ Log (
[Per_PUB] $)+[$ Per_RES] *Log $([$ Per_RES] $)) / \log (3)$
b. If $\left[S U M \_C O M\right]=0 \&\left[S U M \_P U B\right]>0 \&$ [SUM_RES] $>0$ Then
val $=(-1)^{\star}\left([\text { Per_PUB }]^{*} \log ([\right.$ Per_PUB] $)+[$ Per_RES] *Log $([$ Per_RES] )$) / \log (2)$
c. If $\left[S U M \_C O M\right]>0 \&\left[S U M \_P U B\right]=0 \&\left[S U M \_R E S\right]>0$ Then val $=(-1)^{*}\left(\left[\right.\right.$ Per_COM] *Log $\left([\right.$ Per_COM] $)+\left[\right.$ Per_RES] ${ }^{*} \log ($ [Per_RES] ) )/Log ( 2 )
d. If $[$ SUm_COM] $>0 \&$ [SUm_PUB] $>0 \&$ [Sum_RES] $=0$ Then val $=(-1)^{\star}\left(\left[\right.\right.$ Per_COM] ${ }^{*} \log \left([\right.$ Per_COM] $)+[\text { Per_PUB }]^{*}$ Log ( [Per_PUB] ) )/Log ( 2 )
e. Else $\mathrm{val}=0$

\subsection{CALCULATING OTHER INDEPENDENT DATA}

1. Activity Density

a. Add a field 'Sq_Mile'

b. Calculate geometry Area with Square Mile

c. Calculate the field: Population + Employment / Gross Land Area in a square mile

([SUM_I_TOTP]+ [SUM_I_TOTJ])/ [Sq_Mile]

2. Job Population Balance

a. Add a field 'JobPop'

b. Calculate the field: $1-[\mathrm{ABS}(\mathrm{employment}-$

$0.2^{\star}$ population $) /\left(\right.$ employment $+0.2^{\star}$ population $\left.)\right]$

1 - (Abs ([SUM_I_TOTJ] - 0.2* [SUM_I_TOTP]) /( [SUM_I_TOTJ] + $0.2 *$ [SUM_I_TOTP] $)$ )

3. Intersection Density

a. Open Intersection data (In Utah, we downloaded Street Network Analysis file from ArcGIS, and used Junction point file).

b. Intersect the $1 / 2$-mile buffer around stops with points. 
c. Add a field 'Count' with short integer.

d. Dissolve

- Dissolve Field: StopID(or equivalent)

- Statistics Fields: Count

- Statistic Type: SUM

4. Transit Stop Density

a. Open transit stop data (In Utah, we merged bus stops, light rail stops, and commuter rail stops).

b. Intersect the $1 / 2$-mile buffer around stops with transit stops.

c. Add a field 'Count' with short integer.

d. Dissolve

- Dissolve Field: StopID(or equivalent)

- Statistics Fields: Count

- Statistic Type: SUM

5. \% Regional Destinations

a. We have block group level data for some metropolitan areas.

b. Intersect bus stop data with block group data. 


\subsection{PREPARING PARATRANSIT DEPLOYMENT DATA}

1. Add csv file of Paratransit Pickup data in ArcGIS (2013 \& 2018 Data separately).

2. In the table of Contents, right-click on the file and click Display XY Data.

- X Field: Lon

- Y Field: Lat

- Coordinate System of Input Coordinates: WGS 1984

3. Export as a new file.

4. Reproject the file with the local projected coordinate. (Batch Project)

5. Create a quarter mile street network buffer around each stop

i. Network Analyst $>$ New Service Area

ii. Network Analyst Window> Facilities > Load Addresses

- Facilities: Bus Stops

- Sort Field: StopAbbr (StopID)

- Name: StopAbbr (StopID)

- Location Position> Use Geometry> Search Tolerance: 0.25 Miles

iii. Properties> Analysis Settings

- Impedance: Length (Meters)

- Default Breaks: 402.336

iv. Properties> Polygon Generation

- Detailed

- Trim Polygon: 0.25 Miles

v. Properties> Network Locations

- Search Tolerance: 0.25 Miles

6. Intersect Para_2013 with a $1 / 4$ mile Network Buffer

7. Add a field "Count" and put " 1 " in calculation

8. Dissolve the intersected file

- Dissolve Field: Name(StopID)

- Statistics Field: Count

- Statistics Type: SUM 